\title{
Deleting Misconduct: \\ The Expungement of BrokerCheck Records
}

Colleen Honigsberg

Robert J. Jackson, Jr.

Matthew Jacob 


\title{
Deleting Misconduct: The Expungement of BrokerCheck Records
}

\author{
Colleen Honigsberg* \\ Robert J. Jackson, Jr. \\ Matthew Jacob
}

August 2018

\begin{abstract}
We examine the effects of a controversial process, known as expungement, that allows brokers to remove evidence of allegations of financial misconduct from FINRA's public records. We show that brokers who receive expungements are more likely to be accused of misconduct in the future than similarly situated brokers. Using an instrumental variable to address endogeneity in the decision whether to grant an expungement, we study the effect of expungement on recidivism and other career outcomes. We also examine how these consequences vary by gender, ethnicity, and political affiliation. Finally, we offer a note of caution to researchers and investors using BrokerCheck data to study misconduct in the industry, as BrokerCheck data reflect cleansed adviser histories rather than a comprehensive sample of all historical adviser misconduct.
\end{abstract}

Keywords: FINRA Rule 2080, expungement, broker misconduct, recidivism, BrokerCheck

\footnotetext{
* Colleen Honigsberg is an Assistant Professor of Law at Stanford Law School. Robert J. Jackson, Jr. is a Commissioner of the United States Securities Commissioner and a Professor of Law, on public service leave, at New York University School of Law. Matthew Jacob is a Pre-Doctoral Research Fellow in the Department of Economics at Harvard University. The Securities and Exchange Commission, as a matter of policy, disclaims responsibility for private publications or statements by any of its employees, and the views expressed here are solely Commissioner Jackson's and do not necessarily reflect the thinking of the Commission or its Staff. We thank Bobby Bartlett, Jacob Goldin, Joe Grundfest, Justin McCrary, Frank Partnoy, Steven Davidoff Solomon, Jonathan Sokobin, Everett Wilcher and participants at workshops hosted by Berkeley Law and [other schools], for helpful comments. Please direct correspondence to colleenh@law.stanford.edu, jacksonro@sec.gov and mjacob@fas.harvard.edu.
} 


\section{Introduction}

Reputational sanctions play an important role in deterring misconduct (Fama and Jensen (1983), Shavell (1987), Fischel and Sykes (1996)). That is especially so in financial markets, where revelations of misconduct can carry meaningful career consequences. For example, directors are more likely to depart the firm following earnings restatements (Srinivasan, 2005) or financial fraud (Fich and Shivdasani, 2007), and CEOs have difficulty finding new management roles when they leave after regulatory enforcement actions are revealed (Karpoff, Lee and Martin, 2008a). ${ }^{1}$ Recent work on the reputational effects of financial-advisor misconduct, however, reveals a puzzle: even when such misconduct is publicly disclosed in filings with the Securities and Exchange Commission (SEC) and Financial Industry Regulatory Authority (FINRA), the market often imposes a penalty that seems inconsequential. Dimmock and Gerken (2012), for example, show that the fraud propensity for investment advisors can be computed from SEC filings, but find no evidence that investors are compensated for the increased fraud risk associated with such advisors. Egan et al. (2018a) show that brokers with a history of misconduct frequently continue to remain employed as registered broker-dealers - albeit concentrated in select firms. This leads to the questions of why firms and investors don't impose more significant penalties on financial advisors with a publicly available history of misconduct — and whether publicly disclosing the information provides the market with valuable information.

We contribute to the growing literature on this question by examining a common but controversial practice, known as "expungement," that allows brokers to remove evidence of disciplinary infractions from the broker information that FINRA provides to the investing public. Although the expungement process has been the subject of significant policy debate (PIABA, Berkson and Lambert, 2017), to our knowledge no prior work has systematically studied the effects of expungement on the efficacy of reputational constraints. ${ }^{2}$ One reason why is, of course, that expunged information is no longer available on the BrokerCheck website, and thus not easily available for extraction. But expunged infractions can be found, with difficulty, using FINRA's

\footnotetext{
${ }^{1}$ Firms, too, have been shown to suffer reputational sanctions: Karpoff, Lee and Martin (2008b) and Armour, Mayer and Polo (2016) show that reputational losses from regulatory enforcement far exceed the direct monetary fines that firms pay in those cases.

${ }^{2}$ Using credit data, Dobbie, et al. (2017) also study the removal of financial history on personal outcomes.
} 
Arbitration Awards database. By scraping these awards, we identify more than 6,000 broker requests for expungement from 2007 to 2016 and test how consequences for both investors and brokers differ depending on whether the request was successful.

First, we study expungement and broker recidivism. We find that brokers who receive expungements are more likely to be accused of misconduct in the future. We address endogeneity in the decision whether to grant an expungement by constructing an instrumental variable based on proprietary data from FINRA that allows us to identify the initial set of randomly selected arbitrators who will consider the broker's expungement request.

Second, drawing on Egan et al. (2018b), we contribute to the prior literature on genderbased differences in reputational effects in financial markets. Egan et al. (2018b) provides descriptive evidence that women and minorities are punished more severely for disciplinary infractions than white men. We extend these findings by using our instrument to test how the consequences of expungements vary by gender, ethnicity, and political affiliation. Descriptively, we also examine the determinants of filing for expungement and show that women are significantly more likely to apply for expungement - and to have that request granted - than men. Taken together with Egan et al. (2018b), one explanation is that women make more use of the expungement process because the market forgives men for a publicly available history of financial misconduct more readily than it does women.

Finally, our paper contributes to the growing literature using data from BrokerCheck to study how investors respond to publicly available information describing broker misconduct (Qureshi and Sokobin (2015); Egan, Matvos, and Seru (2018a, b)). To our knowledge, our study is the first to examine BrokerCheck records after accounting for the selective removal of evidence of misconduct through the expungement process. The analysis contributes to the ongoing policy debate over expungement, and highlights data issues that arise when using the BrokerCheck data. In particular, researchers should be aware that the infractions in BrokerCheck reflect cleansed adviser histories rather than a comprehensive sample of all historical adviser misconduct. Further, researchers using the data should be cautious in interpreting the lack of employment data in BrokerCheck as indicative of a broker having exited the finance industry. A significant portion of brokers in our expungement sample disappear from BrokerCheck even though they continue to work in the finance industry—-some remain employed at FINRA registered firms but do not 
register, and many switch to the investment advisory side, perhaps because investment advisors are regulated more leniently than broker dealers.

The remainder of the Article proceeds as follows. Part 2 reviews the legal and institutional setting in which brokers request expungement of alleged misconduct. Part 3 describes our data and methodology. Part 4 describes our results, and Part 5 concludes.

\section{Institutional Background}

In the United States, many investor allegations involving financial-adviser misconductanywhere from 3,000 to 9,000 complaints each year — are adjudicated through FINRA's arbitration process (FINRA, 2018). Arbitrations are conducted either by a single factfinder or a panel comprised of three adjudicators, in each case drawn from a group of more than 7,000 arbitrators maintained by FINRA nationwide (FINRA, 2018). ${ }^{3}$

In most instances, FINRA identifies a potential set of arbitrators using the Neutral List Selection System, a computer algorithm that ensures conditional random selection (subject only to minimization of arbitrator travel). Each party to an arbitration is allocated a certain number of strikes to eliminate undesirable candidates. ${ }^{4}$ In investor cases with claims of up to $\$ 100,000$, the general rule is that the claim will be adjudicated by a single arbitrator. The parties receive one list of 10 qualified public arbitrators, and each party has the right to strike up to four arbitrators on the list and rank the remaining six arbitrators (FINRA, 2016). Investor cases involving claims of more than $\$ 100,000$ are typically adjudicated by a panel of three arbitrators. ${ }^{5}$ In these cases, the parties

\footnotetext{
${ }^{3}$ Although as a formal matter arbitrators are not FINRA employees, FINRA is extensively involved in the training and selection of its population of arbitrators (FINRA, 2017). Under FINRA Rule 12214, arbitrators receive $\$ 300$ per hearing session, with an additional $\$ 125$ per day for arbitrators acting as chairperson at a hearing on the merits before a three-member panel.

${ }^{4}$ According to FINRA, "[t] he randomized process [used in NLSS] has been verified by an Ernst \& Young audit in a report that confirmed that a 'random pool management algorithm [is] used to ensure that each arbitrator in the pool has the same opportunity to appear on a list as all other arbitrators in that pool.'”

${ }^{5}$ One arbitrator serves as the chair, the second serves as the public arbitrator, and the third serves as the private arbitrator. In these cases, the parties receive three lists, and all parties have the right to select an all-public panel by striking all of the arbitrators on the non-public list.
} 
receive three lists of ten potential arbitrators, and each party may strike up to four candidates on each list, ranking the remaining arbitrators.

After a customer complaint is settled or adjudicated, the firm or adviser that was the subject of the complaint has an obligation to report that outcome to FINRA's Central Registration Depository (CRD), typically no more than 30 days after learning that a filing is required. ${ }^{6}$ Firms or individuals who fail to file required updates are subject to regulatory action by FINRA. ${ }^{7}$ FINRA then releases some, but not all, of the information in each firm and broker's CRD file to the public on FINRA's BrokerCheck website.

BrokerCheck displays information on all brokers and firms registered with FINRA. These records include information about qualifications, employment history, and disciplinary history. In particular, disciplinary history_in FINRA parlance, "dispute information"-includes written complaints, arbitrations in which the broker is named as a party, litigation that names the broker as a party, arbitration awards, and civil judgments. ${ }^{8}$ An example of how this is presented on BrokerCheck is provided in Appendix I. Although brokers have the opportunity to respond to the allegation in BrokerCheck itself — as shown in the example provided in Appendix I—many brokers do not pursue this option.

One concern with the disciplinary history provided on BrokerCheck is that the information has not been independently verified. A customer complaint against, for example, broker Robert Jackson can be added to CRD—and thus show up in BrokerCheck—without thirdparty verification that Robert Jackson committed a bad act. The process is subject to such little supervision that a completely erroneous allegation — such as a dispute against the wrong Robert

\footnotetext{
${ }^{6}$ FINRA rules currently require the use of six forms for firms and brokers to file with CRD in order to update their records: Form U4 (usually regarding initial applications for securities-industry registration), Form U5 (a non-public record that follows brokers and is used by firms to track employment history and reasons for separation), Form U6 (for reporting certain disciplinary actions), Form BD (for application for broker-dealer registration), Form BDW (for requests for broker-dealers to withdraw from registration), and Form BR (for registration of a broker-dealer's branch office) (FINRA, 2002). State regulators can, and often do, separately provide information regarding actions they have brought to FINRA for inclusion in the CRD.

${ }^{7}$ As Qureshi and Sokobin (2015) point out, FINRA has recently proposed, and the SEC has recently adopted, new rules requiring firms to adopt written procedures to ensure that the information they report to CRD is accurate.

${ }^{8}$ Since 2009, even if the broker is not named as a party in an arbitration or litigation, that proceeding must be reported to $\mathrm{CRD}$ if it is alleged that the broker was involved in a sales practice violation.
} 
Jackson (there are 35 such people on BrokerCheck) — may be recorded in Robert Jackson's BrokerCheck file. ${ }^{9}$

For this reason, there are concerns that the disciplinary information in BrokerCheck is erroneous and that brokers are unfairly penalized. To address these concerns, FINRA allows brokers to expunge their records. The rules governing expungement have been the subject of a great deal of controversy, and therefore have changed extensively over time. From 1981 to 1999 , FINRA's predecessor, the National Association of Securities Dealers (NASD), permitted customer dispute information to be removed from CRD if there was a judgment or arbitration award directing expungement (Lipner, 2013). Then, in early 1999, in response to criticism from state securities regulators, NASD imposed a temporary moratorium on arbitrator awards of expungement (Lipner, 2013). In particular, state lawmakers argued that information in CRD is a "state record" for purposes of certain state laws, thus subjecting CRD to state-law rules governing the alteration or removal of CRD data (Butterworth, 1998).

Three years later, following extensive industry and investor commentary, in November 2002 NASD proposed a new rule, Rule 2130, that now governs expungement requests (the SEC approved Rule 2130, which has since been recategorized as Rule 2080, in 2003). This rule provides arbitrators with guidance on addressing expungement requests and specifies that expungement may only be awarded in cases where the initial case-whether adjudicated by a court or arbitrator-either (1) involved a claim that was "factually impossible or clearly erroneous," (2) involved a complaint where the registered person was not involved in the alleged conduct, or (3) led to CRD information that is "false". The Rule became effective in April 2004, ending FINRA's five-year moratorium on reviewing expungement requests. Rule 2080 only applies to customerrelated disputes. To our knowledge, there is no FINRA rule governing expungement of other disputes (i.e., intra-industry disputes).

Expungement remains controversial today. As recently as late 2017, FINRA requested comment on several options to revamp the expungement process, including creating a new roster of arbitrators with specialized expungement training, shortening the period in which a broker can request expungement, requiring a panel of arbitrators unanimously to agree to grant any expungement, and/or requiring that brokers appear in person at expungement hearings. The period

\footnotetext{
${ }^{9}$ The example given in the text is, of course, purely hypothetical.
} 
to comment on these proposals closed in early 2018, so FINRA may formally propose rule changes for SEC approval in the near future.

\section{Methodology and Descriptive Statistics}

Our analysis uses two datasets: (1) the BrokerCheck data, and (2) the Expungement data. The BrokerCheck data include a balanced panel of 1.23 million brokers available in FINRA's BrokerCheck database from 2007 to 2017. The Expungement data include 4,816 cases against 5,278 unique brokers $(6,088$ brokers in total) that were initiated from 2007 to 2016 . We focused on this time period for three reasons. First, FINRA was created through regulatory consolidation in July 2007, so recordkeeping becomes more consistent at this point. Second, many expungement cases brought in 2017 are yet to conclude. Third, BrokerCheck is meant to display records for a period of 10 years, meaning that data over a decade old becomes subject to an increasingly severe selection bias. We provide detailed information on each dataset below.

\section{BrokerCheck Data}

Our broker-specific information comes from FINRA's BrokerCheck database ${ }^{10}$ BrokerCheck is meant to provide individuals with a free and easy way to research an investment professional before hiring him or her. Subject to limited exceptions, financial professionals who sell securities or offer investment advice are required to register with FINRA and are thus included in BrokerCheck. As such, the scope of BrokerCheck extends beyond traditional customer-facing brokers to include sell-side advisors such as investment bankers.

We scraped BrokerCheck using an algorithm written in Python in May 2018, so our BrokerCheck data contain information on all brokers and firms with records available in BrokerCheck in May 2018. ${ }^{11}$ This yields a balanced panel of 1.23 million brokers spanning the

\footnotetext{
${ }^{10}$ BrokerCheck is a publicly available subset of FINRA's Central Registration Depository (CRD) database, which is a detailed database with information on securities firms and professionals used and maintained by regulators.

11 The algorithm executed an exhaustive search for broker CRD numbers between 1 and 7,000,000 (the end value of 7,000,000 was decided after speaking with the authors of McCann et al. (2016)). After completing the initial scrape, we exported the data into $\mathrm{R}$ and converted the broker cross-section into a panel using the information on broker registration and disclosure histories. If a broker switched firms midway through the year, she was assigned to the firm that she spent the most time at in any given year. If a broker was registered at two firms for an entire year, we randomly selected one firm for the particular year.
} 
period between 2007 and 2017. In total, there are roughly 13.5 million broker-year observations. However, some of these brokers were not active in some (or all) of the years between 2007 and 2017. In these instances, we keep the observation to maintain a balanced panel, but we leave employment blank as employment is only reported for active brokers at FINRA-registered firms.

For each broker identified in BrokerCheck, we pulled the individual-level variables shown in Panel A of Table 1. ${ }^{12}$ The table presents characteristics of the brokers who applied for expungement, the brokers who have not applied for expungement, and t-statistics comparing the two populations. There are clear differences in the populations. Brokers who apply for expungement have more years of experience, are more likely to be retail-brokers and investment advisors, and have far more disclosures. They have also passed more exams, likely because they are retail brokers and must pass the exams required for the state(s) in which they operate. ${ }^{13}$

After completing the scrape of brokers, we generated a unique list of employers and scraped BrokerCheck for information on these firms. As shown in Panel B of Table 1, we identified 8,059 unique firms (however, only 3,755 firms were available in all years). The majority of firms in BrokerCheck do not employ expunged brokers, but those that do tend to be larger, more established, and more client facing. This seems intuitive, as larger firms with more brokers, especially retail brokers, and longer lifespans have more opportunity for the brokers to commit misconduct and expunge that misconduct.

\section{Expungement Data}

Our expungement data contain, as best possible, the complete set of all requests to expunge broker CRD information initiated between 2007 to 2016. We identified the expungement cases using FINRA's Arbitration Awards online database. First we conducted a search of the Arbitration Award online database using the following keywords: 'expungement', '2080' or '2130' (as discussed previously, Rules 2080 and 2130 govern FINRA's expungement procedures for customer-initiated disputes). This search yielded over 10,000 arbitration awards, each uniquely

\footnotetext{
${ }^{12}$ We have far more observations than Egan et al. (2018ab) because we keep observations where the broker's employment information was not available in BrokerCheck (i.e., the broker was not active registered). We keep these observations because many brokers apply for expungement when they are not employed in a FINRA-registered capacity - and thus, their employment information is missing from BrokerCheck. As such, our analysis would exclude a systematically important group of expunged brokers if we were to use only the limited panel.

13 The qualifications represent the number of tests passed by the broker. The most common are Series 63 (state securities regulations), Series 7 (general securities exam), Series 65 and 66 (typically required to provide investment advice), and Series 24 (typically required to serve in a supervisory capacity).
} 
indexed by a FINRA Award ID. Using Python, we scraped this list of FINRA Award IDs and the links to the relevant arbitration award PDFs. Second, using this list of Award ID numbers and PDF links, we used Python to download the PDFs. As a first cut, we identified the 3,500 cases that contained '2080' or '2130' in the award section of the PDF (the simple search of the Arbitration Awards online database for '2080' and '2130' yielded many cases which did not contain '2080' or '2130' in the text of the award). For the remaining PDFs, we similarly used Python to identify those containing 'expungement' in the text of the award and hand-coded these PDFs to confirm they were actually related to expungement proceedings. After removing duplicates, we had 6,100 expungement cases in total.

To gain confidence in our sample and identify further expungements, we reached out to the Public Investors Arbitration Bar Association (PIABA), an international bar association whose members represent investors in disputes with the securities industry. PIABA tracks expungements, and shared with us data from 2007 to 2014 for the purposes of this study. Our initial data included $92 \%$ of the cases in the PIABA data, and we added the missing 227 observations. ${ }^{14}$

After restricting attention to cases filed between 2007 and 2016, our search parameters yielded 4,816 arbitration awards corresponding to 6,088 unique broker-case observations. Descriptive statistics for these observations are presented in Table 2. For each arbitration award, we identified the following variables: Date of award, date of claim, all brokers listed in the PDF, the justification for the expungement under Rule 2080 (False, Erroneous, or Not Involved), whether the case was heard by a panel or sole arbitrator, whether the expungement was successful, whether the case was settled, the hearing site of the case, whether the expungement was unopposed, settlement amounts (when disclosed), who initiated the case (broker, firm, or customer), and the date and type of the underlying infraction (these variables are defined in Appendix 1). To categorize the type of infraction, we used the categories provided in Table 3(a) of Egan et al. (2018a) for customer-initiated cases and created similar categories for broker-initiated cases. We scraped the variables initially using Python, but hand-checked the coding. Finally, after observing the relatively high proportion ( $\sim 40 \%)$ of cases recorded as 'erroneous' under Rule 2080 , we handcollected the number of these cases that were 'truly erroneous'. We classified cases as cases as 'truly erroneous' if any of the following occurred: customer identified the wrong broker in the

\footnotetext{
${ }^{14}$ Our sample included an additional 1,233 cases that were not included in the PIABA data. This discrepancy is largely because PIABA restricts attention to expungement cases involving stipulated awards or settled customer claims.
} 
complaint (e.g., misspelled name or sales assistant), infraction occurred before the broker joined the relevant firm, or broker had no contact with the customer. We found that $18 \%$ of cases recorded as 'erroneous' were 'truly erroneous'. The remaining 'erroneous' cases involved issues such as allegations of excessive risk-taking that did not seem consistent with Rule 2080's guidance.

Using the broker's name, we pulled additional detail about the broker. First, by matching the broker's name with the GenderChecker.com database, we identified the broker's gender. If the broker's first name was not in the database or was unisex, we matched the middle name (or any other name excluding the broker's last name). Second, we ran the broker's name through NamePrism, an ethnicity classification tool. The tool classifies brokers into six categories: White, Black, API (Asian and Pacific Islander), AIAN (American Indian and Alaska Native), Multiple_Race (more than 2 race) and Hispanic. Finally, we use Follow the Money to identify any political donations made by each broker. We present whether the broker contributed to republicans, democrats, both parties, neither party, and the total sum contributed.

Descriptive statistics for the expungements are presented in Table 2, which contains additional information from the BrokerCheck data that has been merged with the Expungement data. To merge these datasets, we use the broker's CRD and the year that the arbitration was decided. The vast majority (99\%) of the brokers who sought expungements appear in the BrokerCheck data (the remaining brokers appeared to drop out because BrokerCheck is only meant to maintain records going back 10 years). However, only $87 \%$ of the brokers that sought expungement are employed at a FINRA-registered firm when the arbitration is decided. Rather than removing these observations from the data, we include the relevant broker characteristics (e.g., number of licenses) from the broker's most recently available year in BrokerCheck. We note that the broker has left the industry, however, and code their employment as such in our panel.

Table 2 first shows the mean, median, and standard deviation for each relevant variable, and then presents these statistics conditional on whether the expungement was successful. Some trends are evident. Brokers are more likely to succeed if the case is not opposed, the broker has settled with the aggrieved party, and the broker does not have a prior expungement. Brokers from larger firms - and firms without disciplinary history - are also more likely to succeed. Women are more likely to be successful than men, and whites are more likely than non-whites.

Further descriptive statistics are presented in Figures 1 through 4. Figure 1 presents the number of successful and unsuccessful expungement awards by year, and shows that 
expungements have a roughly $70 \%$ success rate in each year from 2007 to 2016. Figure 2 presents the number of brokers who sought multiple expungements during our sample period and shows that roughly $7 \%$ (2\%) of brokers seek two expungements (three or more) expungements. At the extreme, one broker expunged his record 39 times. Figure 3 shows the mean settlement for expunged actions by year. In all years from 2007 to 2014, the mean settlement exceeded $\$ 100 \mathrm{~K}$, suggesting that the underlying claims had at least some validity. Notably, mean settlements were lowest in 2015 and 2016, after FINRA prohibited settlements conditioned on expungement, perhaps reflecting the rule change. However, this figure should be interpreted cautiously as we were only able to identify the settlement amount in roughly one-third of cases.

Finally, Figure 4 reflects the arbitrator's Rule 2080 justification for expunging the action (a justification is provided for all successful expungements relating to customer dispute information). The numbers sum to more than $100 \%$ because multiple justifications are often cited. Interestingly, about $40 \%$ of infractions were deemed "erroneous," a high percentage given that the standard suggests "erroneous" reflects cases where, for example, the wrong broker is named. To determine whether the error rate is truly this high, we review these cases by hand and code whether we would consider the case as "erroneous" based on our reading of Rule 2080, which implies that the erroneous standard is to be used if the case is so clearly erroneous that a lay-person would deem it as such (e.g., the broker was not employed at the firm).

A natural question to ask is why all brokers do not expunge their records. To answer this question, we cold-called 554 brokers in our sample. Of these, 100 had successfully expunged an infraction and the remainder had non-expunged misconduct on their public records. Of these 554 brokers, only 19 agreed to speak with us - the remainder immediately hung up, did not return our calls, or hung up after comments such as "I don't know what an expungement is". However, these 19 provided consistent explanations for why brokers do not expunge. First, many brokers are unaware of the process or even that the misconduct can be viewed publicly. Several were very surprised to receive our call, responding with comments such as "you know, your call is the first time I've ever heard this" (referring to the expungement process). Second, of the brokers familiar with the process, many thought it was too costly. The cost mentioned was anywhere from $\$ 12,500$ 
to $\$ 300,000$, with most putting the cost around $\$ 25,000-\$ 50,000$ before settlement payments. ${ }^{15}$ Finally, many of the brokers estimated their likelihood of success to be low, noting that FINRA considers expungement a drastic remedy.

\section{Empirical Analysis}

\section{A. Predictive Value of Expungements}

FINRA describes expungement as "an extraordinary remedy" that "should be used only when the expunged information has no meaningful regulatory or investor protection value." 16 As a preliminary inquiry, therefore, Table 3 tests whether expunged actions predict future misconduct. All models are run using ordinary least squares and control for the broker's years of experience, gender, whether the broker is Caucasian, total qualifications, and whether the broker has passed the following specific exams: Series 65 or 66, 24, 6 and 7. Standard errors are clustered by firm. Fixed effects are included for the broker's firm-county-year. Panels A and B present the results for prior misconduct, prior successful expungements, and prior unsuccessful expungements.

Panel A shows that all three variables predict future misconduct, but to varying degrees. An unsuccessful expungement attempt is by far the greatest predictor - it is associated with a 7-9\% increase in the likelihood of future misconduct. A successful expungement attempt is associated with a $1-2 \%$ increase in the likelihood of future misconduct, and prior misconduct with no attempt to expunge is associated with a $\sim 4.5 \%$ increase in the likelihood of future misconduct. From a policy perspective, this suggests that, contrary to the arbitration instructions, expungements provide investor protection value; even successful expungements are a significant determinant of future misconduct. At a minimum, there appears to be a policy argument in favor of disclosing unsuccessful expungement attempts.

Panel B examines how the predictive value of prior misconduct and expungement varies by gender and race. At a purely descriptive level, Columns (1) through (3) show that women are

\footnotetext{
${ }^{15}$ At the extreme, one broker estimated the cost to be $\$ 700 \mathrm{~K}$ for an expungement. However, this same broker mentioned that he had prior difficulty over a "traffic stop" that we later determined to be assault on a police officer, so we question his credibility.

16 "FINRA Rule 2080 Frequently Asked Questions" available at http://www.finra.org/industry/crd/rule-2080frequently-asked-questions (last accessed on 6/6/2018).
} 
less likely to commit misconduct generally, and are less likely to reoffend after initial misconduct or an unsuccessful expungement. One explanation for this result that we consider below, consistent with Egan et al. (2018)'s finding that women are punished more harshly than men for comparable offenses, is that women who commit misconduct are less likely to continue to work in a FINRA registered capacity and thus cannot commit future misconduct. Columns (4) through (6) suggest that non-white individuals reoffend at the same rate as whites. Although the coefficient on the interaction term is statistically significant in Column (5), we hesitate to find this result meaningful as it is driven largely by one office location (UBS Puerto Rico).

In Panel $\mathrm{C}$, we remove unsuccessful expungement requests and test whether the predictive value of expungements differs depending on specific characteristics of the expungement. First, we distinguish the arbitrator's standards for expungement under Rule 2080: False, Erroneous, or Not Involved. In Columns (1) through (3), we include only those expungements deemed False, Erroneous, or Not Involved, respectively. All three predict future misconduct, but Not Involved is the best predictor (unreported F-tests show that the difference in statistically significant). Columns (4) through (6) examine other award characteristics - namely, settlements and customer opposition. Column (4) splits the expungements by whether there was a positive settlement and shows that expungements with settlements are slightly better predictors than those without. Column (5) splits the expungements by whether a customer opposed the expungement and shows that there is very little difference in the predictive power. Finally, Column (6) uses the natural log of the settlement amount +1 as a predictor, and shows that the value of the settlement in expunged cases is highly predictive of future misconduct — the t-stat is over 120.

In Table 4, we examine who files for expungement. All models are restricted to only those who are eligible to file for expungement-i.e., those with misconduct. This restriction requires that we recreate the BrokerCheck misconduct variable for each expunged action, but we are unable to do so perfectly because we frequently do not know when the original infraction occurred. Instead, because we find that the mean duration between the underlying infraction and the award date is five years, we recreate the panel assuming all expungement awards were five years following the initial infraction. We run the tests at the full panel level, asking whether an eligible broker expunged at any point in our time period. Columns (1) and (2) run the regressions using one observation for each broker, and Columns (3) and (4) run the regressions using each broker-year.

Because the decision to file can be made at either the firm or broker level, we analyze 
determinants for each. A few trends emerge. Women are more likely to apply for expungementperhaps because the repercussions of misconduct are more severe. Brokers with more non-standard licenses are more likely to apply, likely because these are retail brokers with state licenses. Finally, brokers from disciplined/taping firms are more likely to apply for expungement. Disciplined firms are those that have been expelled or had their broker-dealer licenses revoked. Taping firms are those that, roughly stated, are required to tape conversations with customers because they have a significant association with a disciplined firm.

In Table 5, we examine the determinants of a successful expungement. All models include fixed effects for the hearing location and type of disclosure (e.g., criminal, customer dispute, etc.). Panel A uses the full sample of expungements, and the dependent variable is equal to 1 if the expungement was successful (otherwise 0). A few trends are clear. Although prior misconduct and prior unsuccessful expungements are negatively correlated with success, prior successful expungements are positively correlated with success-perhaps because the broker learns the process and procedures. Women are more likely to receive successful expungements. Interestingly, higher settlement values - despite being a significant predictor of future misconduct - are highly correlated with success. One explanation for this result is that, until mid-2014, brokers and customers were allowed to stipulate that, as a condition of the settlement, the customer would not oppose any expungement. Presumably, this raised both settlement values and expungement success.

Panel B separately examines the determinants of "mistaken" successful expungements. This panel omits unsuccessful expungements, and the dependent variable is set to 1 if the broker committed future misconduct. Settlement value is a very significant predictor of an mistaken expungement - entirely consistent with the idea that brokers were paying off customers for expungements, and arbitrators were granting those expungements despite their investor protection value. Interestingly, prior misconduct, prior unsuccessful expungements, and customer opposition are all significantly negatively correlated with erroneous expungements, suggesting that arbitrators may overweight these variables.

In sum, Tables 3 through 5 provide descriptive evidence that expungements-especially unsuccessful expungements-provide investors with significant information about future misconduct. Further, there are systematic differences in who applies for and receives expungement. This presents background for our primary research question: What are the consequences of 
expungement for investors and brokers?

Note to Reader. Unfortunately, we are still waiting on data from FINRA, so Tables 6 and 7 are purely descriptive at this point. However, we hope to run them using an IV analysis in the next draft. FINRA has promised to provide us with the initial randomly selected arbitrators, so the first stage will use the average success rate of the median panel arbitrator relative to the success rate in the region to predict success. The second stage will use the predicted success value from the first stage to estimate recidivism and career consequences. We present the results descriptively for now, and we would love to hear your thoughts on the proposed design.

\section{$\underline{1^{\text {st }} \text { Stage }}$}

Success $=\alpha+\beta[$ Average Success Rate of Median Arbitrator - Average Success Rate of Regional Arbitrators] + controls + fixed effects $\underline{2^{\text {nd }} \text { Stage }}$

Career Consequence $=\alpha+\beta[$ Predicted Success $]+$ controls + fixed effects

As a preliminary analysis, Table 6 considers expungement and recidivism. This table analyzes the characteristics that increase the likelihood that, conditional on a misconduct (or expunged misconduct) (between 2007-2016), the broker has another misconduct (or expunged misconduct). To that end, we restrict the sample to brokers who have a misconduct (or expunged misconduct) between 2007-2016. For each broker, we determine the year of their earliest expungement or misconduct. We then create a dummy variable for whether the broker records another misconduct (or expunged misconduct) in any future year-this is the dependent variable. The variable of interest is a dummy for whether the broker ever had an expungement

There is a relationship between expungement and recidivism as shown in Column (1) (17\% increase). This effect, however, is partially mechanical due to the way we define the dependent variable. To isolate this mechanical effect, we run separate regressions for successful and unsuccessful expungements in Column (2) and (3), respectively. We find that that unsuccessful expungements are substantially more predictive ( $40 \%$ increase) of recidivism than successful expungements $(\sim 7.5 \%$ increase). This suggests that arbitrators are, in a sense, getting it 'right' by denying expungements to brokers who are more likely to be repeat offenders. In Columns (4) through (12), we run cross-sectional tests to look for variation by gender, race, or political contributions. We find slight variation by gender - females are less likely to reoffend both 
unconditionally and conditional on having an expungement We find more variation by political contribution. Unconditionally, donors to both parties are significantly more likely to reoffend than non-donors, but conditional on having an expungement, they are less likely to reoffend.

In Table 7, we examine other career outcomes. Panels A and B present descriptive statistics, and Panels $\mathrm{C}$ through E present the corresponding regressions. Specifically, in Panel A, we compare the likelihood that a broker will separate from her current employer within a year after no misconduct, after misconduct, after a successful expungement, and after an unsuccessful expungement. Further, conditional on a broker leaving the firm, we estimate the likelihood that a broker will continue to work as a registered broker-dealer under each of the four scenarios. The key takeaway is that $71 \%$ of brokers with a successful expungement join another firm as a registered broker, whereas only $56 \%$ of brokers with unsuccessful attempts do the same. Panel B presents complementary descriptive statistics and shows a similar trend. This panel uses only the brokers who are not working as a registered broker at time $=\mathrm{t}$ and shows the percentage of brokers with successful and unsuccessful expungements who return to work in a registered capacity. As would be expected based on Panel A, more brokers with successful expungements return to work as registered brokers than those with unsuccessful expungements.

Panels $\mathrm{C}$ through E present regressions examining these trends in more detail. Panels $\mathrm{C}$ and $\mathrm{D}$ examine trends for brokers who were registered at the time of the misconduct or expungement, and Panel E examines trends for brokers who were not registered at time $=\mathrm{t}$.. Panel $\mathrm{C}$ begins by examining separation for brokers employed in a registered capacity at time $=\mathrm{t}$ (i.e., the likelihood that a broker who is registered at the time of the misconduct or expungement will leave her firm). The analysis shows that brokers with a misconduct or unsuccessful expungement at time $=\mathrm{t}$ are more likely to separate from their firms, while brokers with successful expungements are less likely to separate. Consistent with Egan et al. (2018b), there is also evidence that the relationship between misconduct and separation is stronger for women and non-whites, but we do not find this same relationship for the expungement variables.

Panel D examines re-employment for these same brokers - that is, the likelihood that the broker will separate and find registered employment versus "exiting" the industry. The analysis indicates that brokers with prior misconduct or unsuccessful expungement attempts are less likely to re-gain employment in a registered capacity. These patterns seem especially pronounced for women. Columns (4) and (6) show that women are significantly less likely than men to re-gain 
employment as a registered broker following a misconduct or unsuccessful expungement, respectively. However, there does not appear to be any difference in the likelihood of exit for brokers with a successful expungement - these brokers are not statistically different from brokers with an entirely clean record.

Finally, Panel E examines the brokers who work in a registered capacity at some point during our sample period, but are not employed as registered brokers at time $=\mathrm{t}$. The dependent variable in Panel $\mathrm{E}$ is a dummy set to 1 if the broker goes from unregistered to registered in time t+1 (i.e., if the broker "re-enters" the BrokerCheck database). The analysis shows that brokers with misconduct and unsuccessful expungements at time $=\mathrm{t}$ are less likely to re-gain employment in a registered capacity. Interestingly, the magnitudes for these variables are similar, suggesting that the market does not distinguish between misconduct and misconduct that was not expungedalthough the latter is a far better predictor of future misconduct. It is also interesting that, similar to Panel D, brokers with successful expungements are not statistically different from brokers without any misconduct.

Despite the prior evidence that successful and unsuccessful expungements predict future misconduct, Panels D and E suggest that the market does not distinguish between brokers with entirely clean records (i.e., no misconduct at any point) versus brokers who appear clean because they have expunged their records. Similarly, Table E suggests that markets do not distinguish between brokers with misconduct and brokers with non-successful expungements when hiring non-registered brokers. Obviously there is heterogeneity across firms, but one explanation for these trends is that some brokerage houses want the appearance of hiring clean brokers-perhaps to appear clean to customers or regulators-but are less concerned by whether a broker will commit misconduct. Although it is more difficult to identify expungements than to identify misconducts on BrokerCheck, doing so is manageable - especially for a brokerage with a large HR department. It seems plausible that some brokerages already do so. Goldman Sachs, for example, does not hire a single broker with an expunged misconduct. Even the Goldman brokers in our sample who received misconduct allegations while at Goldman were typically no longer Goldman employees by the time of the arbitration (i.e., it appeared these brokers were pushed out before the arbitration process).

To better understand the firms most likely to employ expunged brokers, Panel A of Table 8 presents the firms with the most expunged brokers (only firms with 100 or more brokers are 
included). Column (1) presents the firms with the greatest absolute number of expungements. Column (2) presents the firms with the greatest number of expungements relative to total misconducts (i.e., the total number of possible expungements). ${ }^{17}$ Column (3) presents the firms with the highest percentage of expungements relative to total brokers. Finally, Column (4) presents the firms with the highest percentage of expungements relative to retail brokers (as discussed previously, retail brokers are more likely to have misconduct on their records).

A few trends are evident. Brookville Capital Partners, NSM Securities, RW Towt, and ITRADEDIRECT.COM have been expelled from FINRA membership. Because the number of brokers with adverse disciplinary history is a factor in aspects of FINRA regulation (e.g., it affects the frequency of examinations), one must question whether firms facing severe discipline encourage their brokers to get expungement in order to evade regulatory scrutiny. There also appear to a number of firms that operate as platform companies for individual brokers (e.g., LPL and Securities America). There could be significant variability in quality/compliance at these firms - and in the incentive structure for the firm to take on a potentially problematic broker. Finally, although not evident from the table itself, we note that a number of expunged actions brought at larger firms such as Morgan Stanley were related to unusual products (e.g., Lehman structured notes). This was not the case at smaller, more traditional retail brokerages.

Of course, however, the trends in Table A only describe the brokers who remain registered brokers. A related question is what happens to the brokers who no longer remain registered brokers. We address this question descriptively by reviewing employment history for 1,515 randomly selected brokers who applied for expungement and experienced at least one separation. For the observations with missing employment information, we hand-collect the information as best possible. The results are presented in Panel B of Table 8.

Although we find that brokers who leave their firm end up in a variety of circumstancestwo in prison, for example - the majority remain in finance. As evident from earlier tables, most switch to other FINRA-registered firms and continue to work as registered brokers. However, even

\footnotetext{
${ }^{17}$ As noted earlier, we follow Egan et al. (2018) in considering six of the 23 disclosure categories to be "misconduct." These six categories are as follows: Customer Dispute-Settled, Regulatory-Final, Employment Separation After Allegations, Customer Dispute - Award/Judgment, Criminal - Final Disposition, Civil-Final (other disclosures include, for example, liens and bankruptcies). Although it is rare for a broker to expunge disciplinary infractions that do not meet our definition of expungement, it does occur in some instances, which this is why some firms in Column (2) of Panel A, Table 8 have more expungements than misconducts.
} 
those that no longer appear in BrokerCheck typically continue to work in finance. They fall into two groups. First, some continue to work for FINRA-registered firms, but are no longer registered. This group may not work in a capacity that requires them to register, but it seems likely that many are violating the registration rules. Upon reviewing their LinkedIn profiles, it was clear that some continue to engage in the buying and selling of securities. Second, many of these individuals switch from the broker-dealer side to the investment advisor side (registered investment advisers are regulated primarily by the SEC rather than FINRA). As one such example, consider Kimon P. Daifoitis - the man who applied for expungement 39 times. He eventually went to work as the Chief Investment Officer for Fixed Income at Charles Schwab Investment Management, a registered investment adviser (i.e., not a FINRA-registered brokerage firm), until he was barred from the industry by the SEC.

Panel B of Table 8 summarizes the post-separation outcomes for this sample of brokers. First, we review career switches before an expungement attempt. There are 1,275 separations (799 unique brokers), and 1,147 show up in BrokerCheck because the broker continued to work in a registered capacity. Another 44 switches were to financial firms - 23 to unregistered financial firms, and 21 to FINRA registered firms but the broker was not registered. Of the other switches, 14 were to non-financial companies, 63 were unable to be determined, and the remaining switches were to government, non-profit, education, or self-employed capacities (or folks who retired).

Next, we review switches after a successful expungement. There are 599 switches (396 unique brokers), and 408 show up in BrokerCheck because the broker continued to work in a registered capacity. However, another 56 switches are to other financial firms - 28 to unregistered financial firms, and 28 to FINRA registered firm but the broker was not registered. Of the other switches, 33 were to non-financial companies, 86 were unable to be determined (presumably, many of these people have no online career presence because they are unemployed), and the remaining switches were to government, non-profit, education, or self-employed capacities.

Finally, we review career switches after an unsuccessful expungement. There are 355 switches (240 unique brokers), and 164 show up in BrokerCheck because the broker continued to work in a registered capacity. However, another 52 switches are to other financial firms - 35 to unregistered financial firms, and 17 to FINRA registered firms but the broker was not registered. Of the other switches, 12 were to non-financial companies, 84 were unable to be determined, and the remaining switches were to government, non-profit, education, or self-employed capacities. 
In sum, Panel B of Table 8 shows that brokers who cease employment as registered brokers often continue to work in finance-especially those who exit after an expungement. This has significant policy implications, as it suggests that "bad" brokers may be pushed to other areas of finance that have more limited public disclosure. If so, these individuals may be harder for consumers and regulators to detect. It is also noteworthy that a greater percentage of individuals work for FINRA-registered firms — but not in a registered capacity—after expungements. Because BrokerCheck removes information on brokers who have not been registered for ten or more years, these brokers could be acting strategically; by avoiding registration for ten years, they could cleanse their records-in effect, expunging misconduct without going through the arbitration process.

\section{Conclusion}

We provide the first large-scale analysis of the expungement process that allows brokers to remove evidence of allegations of financial misconduct from FINRA's public records. Our paper has significant policy implications, as we show that brokers who receive expungements are more likely to be accused of misconduct in the future than similarly situated brokers. Further, using an instrumental variable to address endogeneity in the decision whether to grant an expungement, we study the effect of expungement on recidivism and other career outcomes. We show that brokers with unsuccessful expungements are less likely to work as registered brokers going forward, but that most continue to work in finance - either in an unregistered capacity at a FINRAregistered brokerage or in another finance role (usually as an investment adviser). 


\section{References}

Alexander, Cindy R. On the Nature of the Reputational Penalty for Corporate Crime: Evidence. Journal of Law and Economics 42: 489-514 (1999).

Armour, John, Colin Mayer and Andrea Polo. Regulatory Sanctions and Reputational Damage in Financial Markets. Working paper. 2016.

Berkson, Hugh D. and Marnie C. Lambert. BrokerCheck: The Inequality of Investor Access to Information Remains Unabated. Working paper. 2017.

Dimmock, Stephen G. and William C. Gerken. Predicting Fraud by Investment Managers. Journal of Financial Economics 105: 153-173. 2012.

Dobbie, Will, Benjamin J. Keys, and Neale Mahoney. Credit Market Consequences of Credit Flag Removals. Working paper. 2017.

Egan, Mark, Gregor Matvos, and Amit Seru. The Market for Financial Adviser Misconduct. Journal of Political Economy (forthcoming 2018).

Fama, Eugene F. and Michael Jensen. Agency Problems and Residual Claims. Journal of Law and Economics 26: 327-349. 1983.

Financial Industry Regulatory Authority. Dispute Resolution Statistics. Available at http://www. finra.org/arbitration-and-mediation/dispute-resolution-statistics. 2018.

Financial Industry Regulatory Authority. Arbitrator Selection. Available at http://www. finra.org/arbitration-and-mediation/arbitrator-selection. 2016.

Financial Industry Regulatory Authority. Uniform Forms Reference Guide. Available at http://www.finra.org/sites/default/files/AppSupportDoc/p005263.pdf. 2002.

Financial Industry Regulatory Authority. FINRA Office of Dispute Resolution: Arbitrator's Guide. 2017.

Fich, Eliezer and Anil Shivdasani. Financial Fraud, Director Reputation, and Shareholder Wealth. Journal of Financial Economics 86: 306-336. 2007.

Fischel, Daniel and Alan O. Sykes. Corporate Crime. Journal of Legal Studies 25: 319-344 (1996).

Gennaioli, Nicola, Andrei Shleifer, and Robert Vishny. Money Doctors. Journal of Finance 70: 91-114. 2015.

Guiso, Luigi, Paola Sapienza, and Luigi Zingales. Trusting the Stock Market. Journal of Finance 63: 2557-2600. 2008. 
Karpoff, J. M.,; D. S. Lee; and G. S. Martin. "The Consequences to Managers for Financial Misrepresentation.” Journal of Financial Economics, 88 (2008a), 193-215.

Klein, Benjamin and Keith B. Laffler. The Role of Market Forces in Assuring Contractual Performance. Journal of Political Economy 89: 615-641. 1981.

Lipner, Seth E. The Expungement of Customer Complaint CRD Information Following the Settlement of a FINRA Arbitration. Fordham Journal of Corporate and Financial Law 19: 57108. 2013.

Qureshi, Hammad and Jonathan Sokobin. Do Investors Have Valuable Information About Brokers? FINRA Office of the Chief Economist Working Paper. 2015.

Shapiro, Carl. Premiums for High Quality Products as Returns to Reputations. Quarterly Journal of Economics 98: 659-680 (1983).

Shavell, Steven. The Optimal Use of Nonmonetary Sanctions as a Deterrent. American Economic Review 17: 584-92. 1987.

Srinivsan, Suraj. Consequences of Financial Reporting Failure for Outside Directors: Evidence from Accounting Restatements and Audit Committee members. Journal of Accounting Research 43: 291-334. 2005.

Junting Ye, Shuchu Han, Yifan Hu, Baris Coskun, Meizhu Liu, Hong Qin and Steven Skiena. Nationality Classification using Name Embeddings. CIKM, Singapore, Nov. 2017, pp. 1897-1906. 
Appendix I - BrokerCheck Disciplinary History. FINRA's BrokerCheck website displays the number of disclosures for each broker, and users can click for more detail on each specific disclosure. Below we present an example of how the disclosure information is presented in BrokerCheck.

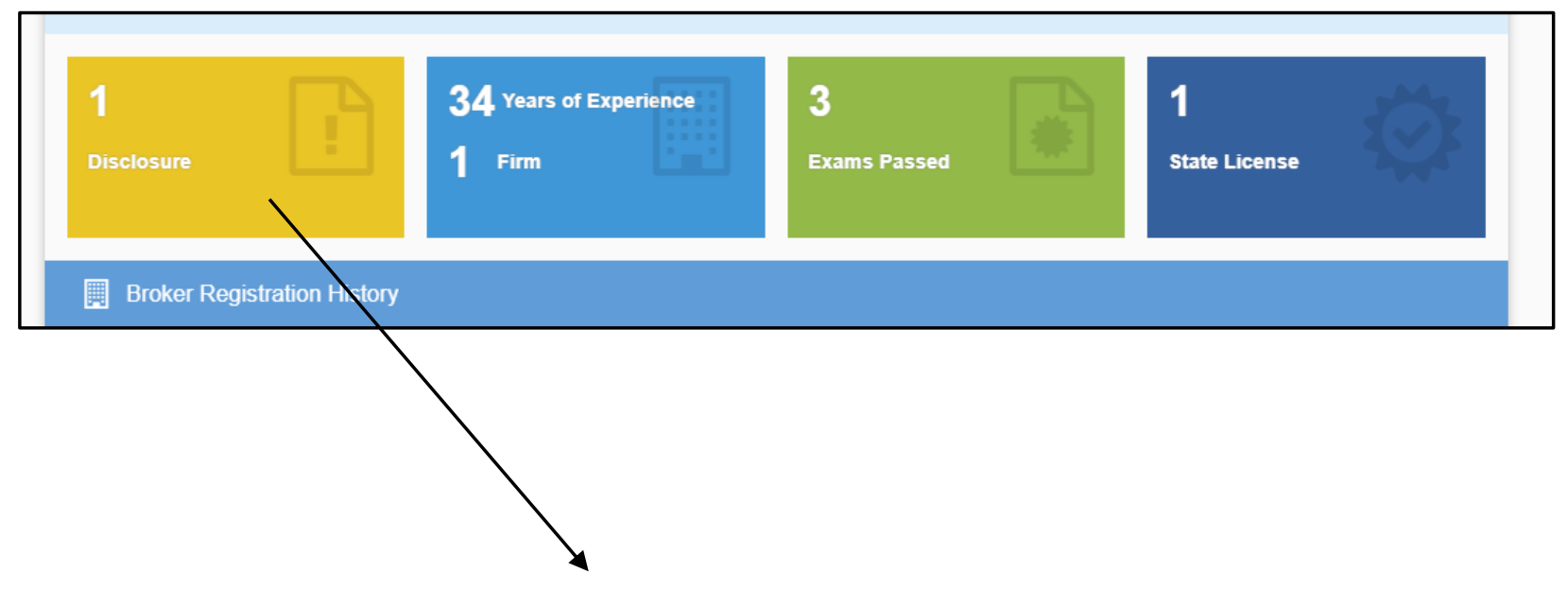

\section{[i] Disclosures 0}

Employment Separation After Allegations

A

Firm Name

PRUCO SECURITIES, LLC

Termination Type

Voluntary Resignation

Allegations

REGISTERED REPRESENTATIVE CREATED NON-GENUINE CLIENT SIGNATURES ON VARIOUS DOCUMENTS. ALLEGATIONS CONFIRMED.

Broker Comment DURING MY EMPLOYMENT WITH PRUDENTIAL \& PRUCO SECURITIES, NO ALLEGATIONS WERE MADE OF ME THAT WOULD FALL UNDER MY UNDERSTANDING OF THE WORD "FRAUD". AND I DEFINITELY WAS NEVER ACCUSED OF THE WRONGFUL TAKING OF PROPERTY. 
Appendix II - Data Pulled from Arbitration Awards. Below we summarize the information we retrieved from the expungement arbitration awards.

\section{Scraped Variables}

- FINRA_Ref

This the number FINRA has assigned to each award. The award number does not uniquely identify a case - that is, multiple award numbers may refer to one arbitration case. Thus, duplicates were removed during the hand-collection.

- Rule

This refers to the rule under which expungement was granted. Only cases pertaining to customer disputes will list a rule; a broker-firm dispute regarding a Form-U5 issue will not cite a rule.

- Erroneous

Dummy variable where " 1 " indicates expungement was granted under Rule 2080's "[t]he claim, allegation, or information is factually impossible or clearly erroneous" standard (it includes variations such as simply "the claims are erroneous").

This variable was checked by hand after scraping.

- False

Dummy variable where " 1 " indicates expungement was granted under Rule 2080's

"[t] he claim, allegation, or information is false" standard.

- Involved

Dummy variable where " 1 " indicates expungement was granted under Rule 2080's "[t]he registered person was not involved in the alleged investment-related sales practice violation, forgery, theft, misappropriation, or conversion of funds" standard. This variable was checked by hand after scraping.

- Success

Dummy variable for whether or not an expungement was successful, where "1" indicates success.

- Panel

Dummy variable for whether a case was heard by a panel of three arbitrators or a single arbitrator, where " 1 " indicates that it was heard by a panel.

- Award Date

This corresponds to the "Date of Award" column from the Arbitration Awards Online section of FINRA's website.

- Hearing Site

This corresponds to where the arbitrator was held and can be found on the first page of the award.

- Settlement

Dummy variable where " 1 " indicates that the complaint was settled.

- Form U5

Dummy variable where " 1 " indicates that the award contained the phrase "Form U5".

\section{$\underline{\text { Hand Collected Variables }}$}


- Claim Date

Date that the claim was filed according to the FINRA award. This can be found in the "Case Information" section and is preceded by the phrase "Statement of Claim filed".

- Unopposed

Dummy variable set to " 1 " if the request for expungement was unopposed by the customer. If a customer was present or arguments were heard it was marked as opposed. To determine unopposed, we made use of phrases in the award such as "unopposed expungement", "opted not to participate in the expungement hearing", or similar phrases that indicated the customer was not involved or was not raising objections to expungement.

- $\mathrm{CRD}$

This corresponds to the CRD numbers for each broker in an award. In rare instances, multiple brokers requested expungement and the arbitrator reached a split decision. In such instances, only CRD numbers for the successfully expunged brokers were recorded.

\section{- Firm CRD}

This corresponds to the firm CRD for each broker in an award. If there were multiple brokers and the arbitrator reached a split decision, only firm CRD numbers for the successfully expunged brokers were recorded. When multiple firms were listed for a single broker, the firm where the broker was most recently employed prior to the award was included.

- Settlement/Damages

This variable reflects the dollar value of settlement or damages mentioned in an award. This amount is frequently not disclosed, in which case we leave the observation blank.

- Complaint Initiation

This variable indicates who filed the complaint that gave rise to the FINRA award. The complaint could have been filed by a customer, broker, or firm.

Customer initiated - Customer initiated awards are those where a customer filed the complaint and was listed as the claimant on the FINRA award. Broker initiated - These are awards in which a broker filed the complaint and is listed as the claimant on the FINRA award. The broker can file a complaint against a customer to expunge an award from their record. Additionally, a broker can be named a claimant when they bring a complaint against a firm over either employment disputes, expungement of a customer complaint, or expungement of their industry employment record (i.e., U5).

Firm initiated - Occasionally, firms will file complaints against either brokers or customers and are named the claimant in a given award. Firms will bring complaints against a customer to seek expungement either for themselves or for their brokers. An award brought against a broker usually involves a business dispute.

- Intra Industry

This is a dummy variable set to 1 if the dispute concerned only FINRA registered firms and their employees. In intra-industry complaints, there are two kinds of cases: those brought by firms against brokers and those brought by brokers against their firms. Broadly, these two kinds of complaints are (1) employment-related such as 
wrongful termination and 2) U4/U5 related, as brokers may bring cases against their former firms to have their U5 and U4 cleansed (these are FINRA-required forms that contain a record of complaints against the broker).

- Who Pays

Variable to indicate whether the firm, broker, or both paid any damages/settlement noted in the award.

- Infraction Date

This is the earliest date of wrongdoing mentioned in an award. Most of the analysis using this variable was collapsed to an infraction year due to inconsistent reporting of the date of the actual offense from case to case.

- Unsuitable

The award states in its cause of action that a given investment or investment advice was unsuitable.

- Misrepresentation

The award states in its cause of action that a broker misrepresented critical information.

- Unauthorized

The award states in its cause of action that a broker initiated unauthorized trades or transactions.

- Omission

The award states in its cause of action that a broker omitted critical information.

- Fee/Commissions

The award states in its cause of action a reference to fees/commissions.

- Fraud

The award states in its cause of action fraud.

- Fiduciary duty

The award states in its cause of action a breach of fiduciary duty or simply "duty".

- Negligence

The award states in its cause of action negligence. Some awards claimed "negligent misrepresentations" as a cause of action. This would be recorded as a " 1 " for both "Misrepresentations" and "Negligence".

- Risky

The award states in its cause of action that an investment-related decision was risky, over-concentrated, or illiquid.

- Churning/Excessive Trading

The award states either "churning" or "excessive trading" in its cause of action

- Other

The award states something other than the prior ten categories as a cause of action.

- Slander Libel Defamation

This is where the award explicitly mentions slander, libel, or defamation as a cause of action in an intra-industry complaint. This is typically regarding information published by a firm regarding the broker's record.

- Interference

This is a claim that the other party - either firm or broker(s) - interfered with the broker's business in an intra-industry complaint (e.g., contacted a broker's customers or took a client list). 
- Unfair Practices

This is like the interference claim and usually involves unfair competition as part of an intra-industry complaint (e.g., a broker claims that the firm terminated his franchise agreement and forced him to sell his practice below fair value).

- Wrongful Termination

Dummy variable for whether wrongful termination was explicitly mentioned as a cause of action in the award in an intra-industry complaint.

- Other Employment Related

Dummy variable for whether the cause of action in an intra-industry complaint did not fit the prior four categories.

- Truly Erroneous

Dummy variable for whether a case expunged under the "erroneous" standard would be interpreted by the lay person as erroneous (e.g., broker was not employed at the relevant firm at the time of the offense, broker was misnamed in the case filing, or broker had no contact with client). 
Figure 1. This figure shows the number of successful and unsuccessful expungement claims filed between 2007 and 2016.

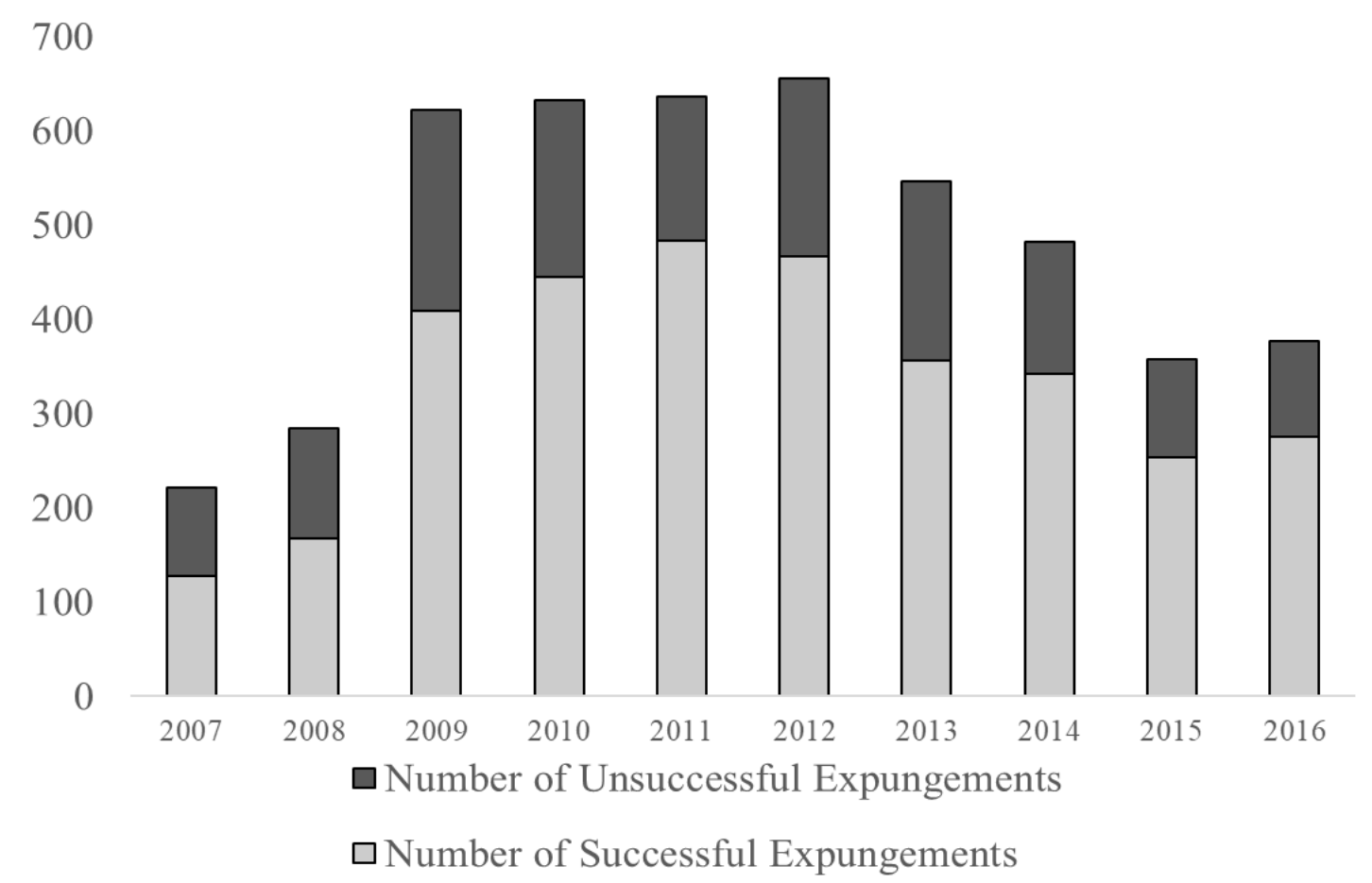

Figure 2. This figure shows the proportion of expunged brokers who filed one, two or more than three expungements between 2007 and 2016.

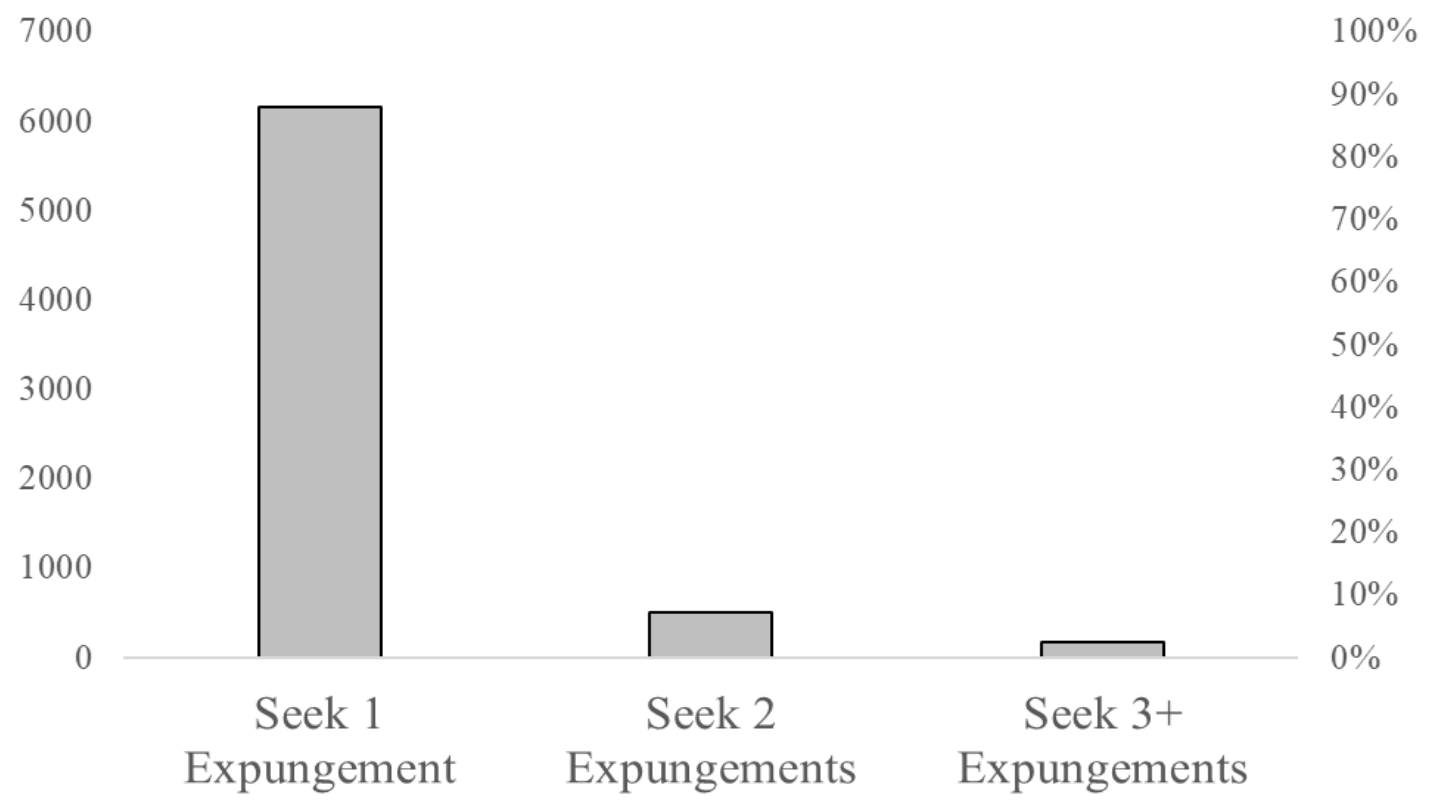


Figure 4. This figure shows the average settlement amount (where disclosed) for arbitrations involving a request for expungement filed between 2007 and 2016.

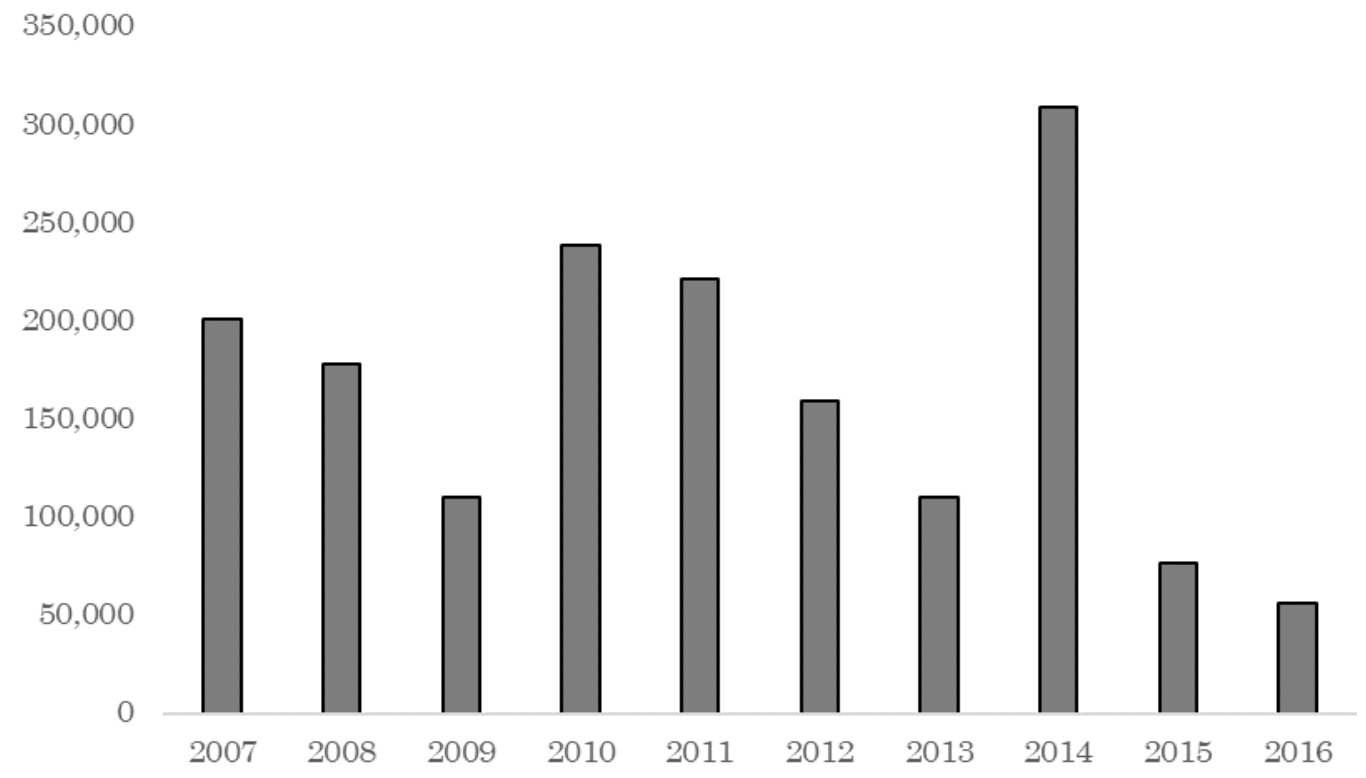

Figure 5. This figure shows the breakdown of the FINRA Rule 2080 justification cited for successful expungements filed between 2007 and 2016. Percentages exceed 100\% because many expungement awards cite more than one justification.

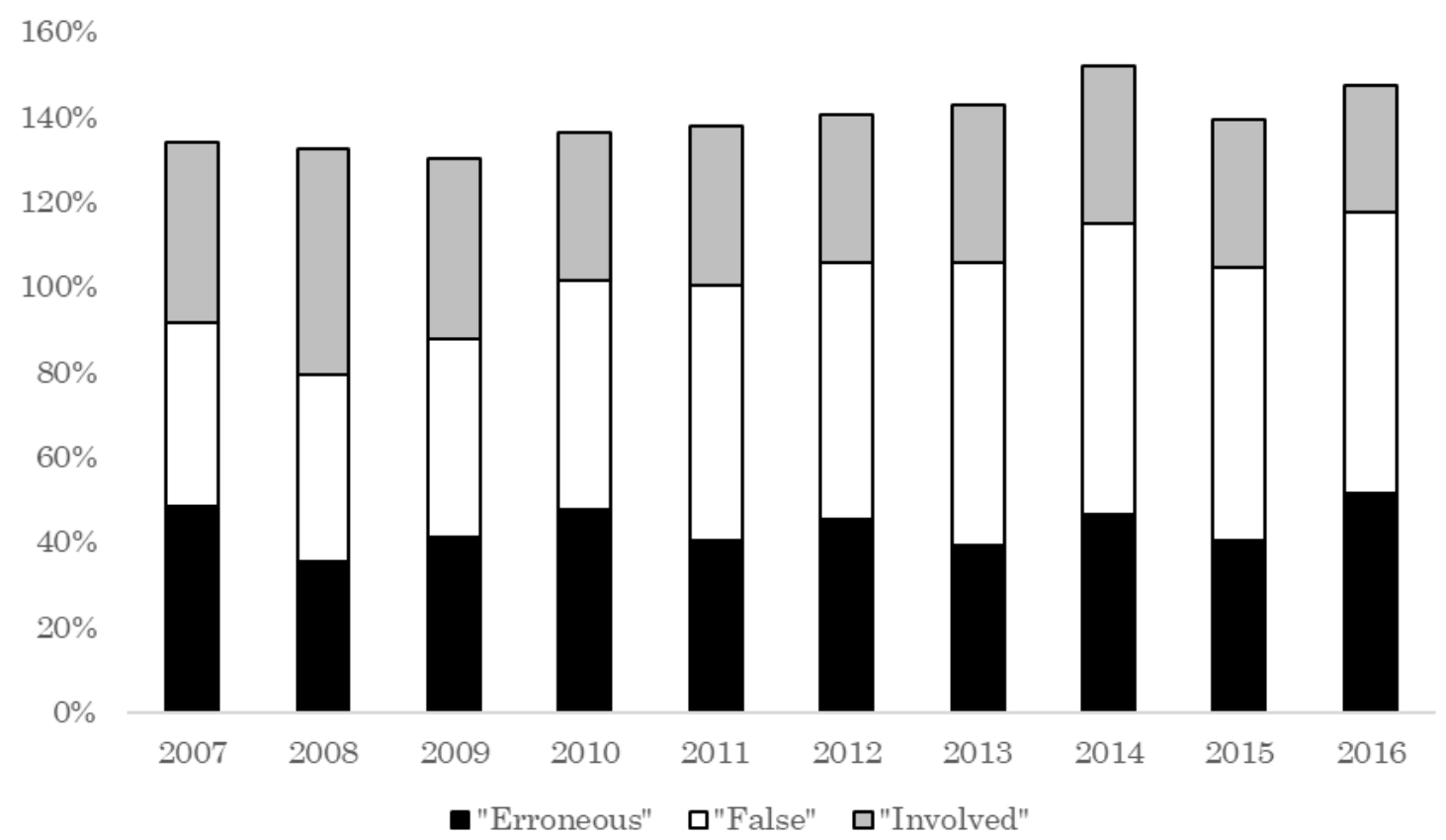


Table 1. Panel A. This table provides summary statistics for brokers from the BrokerCheck data. The BrokerCheck data include a balanced panel of 1.23 million brokers available in FINRA's BrokerCheck database from 2007 to 2017. Observations are adviser by year. The panel is divided into two groups - Non-Expungement Brokers and Expungement Brokers. Expungement Brokers are those who participated in at least one FINRA Arbitration between 2007 and 2017 involving a request for expungement. Non-Expungement brokers are analogously defined. The final column corresponds to a t-test for equality of means between the two groups. Statistical significance of $10 \%, 5 \%$, and $1 \%$ is represented by $*, * *$, and $* * *$, respectively.

\begin{tabular}{|c|c|c|c|c|c|c|c|c|c|c|c|c|c|}
\hline & \multicolumn{6}{|c|}{ Non-Expungement Brokers } & \multicolumn{6}{|c|}{ Expungement Brokers } & \multirow{2}{*}{$\frac{t \text {-test }}{\mathrm{t}}$} \\
\hline & Obs. & Mean & Std. Dev. & Median & 25th Pctl. & 75th Pctl. & Obs. & Mean & Std. Dev. & Median & 25th Pctl. & 75th Pctl. & \\
\hline Experience (Years) & $13,438,634$ & 10.93 & 10.28 & 8.00 & 2.00 & 17.00 & 57,189 & 22.79 & 9.83 & 22.00 & 16.00 & 30.00 & $-287.68^{* * *}$ \\
\hline Retail Brokers & $13,438,634$ & 0.25 & 0.43 & 0.00 & 0.00 & 0.00 & 57,189 & 0.64 & 0.48 & 1.00 & 0.00 & 1.00 & $-191.75^{* * * *}$ \\
\hline \multicolumn{14}{|l|}{ Registration } \\
\hline Registered BD & $13,438,634$ & 0.52 & 0.50 & 1.00 & 0.00 & 1.00 & 57,189 & 0.72 & 0.45 & 1.00 & 0.00 & 1.00 & $-108.39 * * *$ \\
\hline Investment Advisor & $13,438,634$ & 0.39 & 0.49 & 0.00 & 0.00 & 1.00 & 57,189 & 0.82 & 0.38 & 1.00 & 1.00 & 1.00 & $-266.75 * * *$ \\
\hline Barred & $13,438,634$ & 0.01 & 0.08 & 0.00 & 0.00 & 0.00 & 57,189 & 0.02 & 0.13 & 0.00 & 0.00 & 0.00 & $-19.36^{* * *}$ \\
\hline \multicolumn{14}{|l|}{ Disclosures } \\
\hline Disclosure (flow in one year) & $13,438,634$ & 0.01 & 0.11 & 0.00 & 0.00 & 0.00 & 57,189 & 0.09 & 0.29 & 0.00 & 0.00 & 0.00 & $-65.94 * * *$ \\
\hline Misconduct (flow in one year) & $13,438,634$ & 0.00 & 0.07 & 0.00 & 0.00 & 0.00 & 57,189 & 0.06 & 0.23 & 0.00 & 0.00 & 0.00 & $-54.78 * * *$ \\
\hline Expungement (flow in one year) & $13,438,634$ & 0.00 & 0.00 & 0.00 & 0.00 & 0.00 & 57,189 & 0.10 & 0.30 & 0.00 & 0.00 & 0.00 & $-79.12 * * *$ \\
\hline Disclosure (stock) & $13,438,634$ & 0.10 & 0.30 & 0.00 & 0.00 & 0.00 & 57,189 & 0.52 & 0.50 & 1.00 & 0.00 & 1.00 & $-200.93 * * *$ \\
\hline Misconduct (stock) & $13,438,634$ & 0.04 & 0.20 & 0.00 & 0.00 & 0.00 & 57,189 & 0.39 & 0.49 & 0.00 & 0.00 & 1.00 & $-170.41 * * *$ \\
\hline Expungements between 2007-2017 & $13,438,634$ & 0.00 & 0.00 & 0.00 & 0.00 & 0.00 & 57,189 & 1.00 & 0.00 & 1.00 & 1.00 & 1.00 & $\cdot$ \\
\hline Disclosure (stock - inc. pre-2007) & $13,438,634$ & 0.16 & 0.37 & 0.00 & 0.00 & 0.00 & 57,189 & 0.62 & 0.48 & 1.00 & 0.00 & 1.00 & $-228.43 * * *$ \\
\hline Misconduct (stock - inc. pre-2007) & $13,438,634$ & 0.09 & 0.29 & 0.00 & 0.00 & 0.00 & 57,189 & 0.48 & 0.50 & 0.00 & 0.00 & 1.00 & $-185.65 * * *$ \\
\hline \multicolumn{14}{|l|}{ Exams and Qualifications } \\
\hline Num. Qualifications & $13,438,634$ & 2.61 & 1.36 & 2.00 & 2.00 & 3.00 & 57,189 & 3.97 & 1.59 & 4.00 & 3.00 & 5.00 & $-204.31 * * *$ \\
\hline Uniform Sec. Agent St. Law (63) & $13,438,634$ & 0.71 & 0.45 & 1.00 & 0.00 & 1.00 & 57,189 & 0.85 & 0.35 & 1.00 & 1.00 & 1.00 & $-94.46 * * *$ \\
\hline General Sec. Rep (7) & $13,438,634$ & 0.62 & 0.48 & 1.00 & 0.00 & 1.00 & 57,189 & 0.92 & 0.27 & 1.00 & 1.00 & 1.00 & $-257.26 * * *$ \\
\hline Inv. Co. Products (Rep). (6) & $13,438,634$ & 0.40 & 0.49 & 0.00 & 0.00 & 1.00 & 57,189 & 0.17 & 0.37 & 0.00 & 0.00 & 0.00 & $150.31 * * *$ \\
\hline Uniform Combined St. Law (66) & $13,438,634$ & 0.22 & 0.41 & 0.00 & 0.00 & 0.00 & 57,189 & 0.28 & 0.45 & 0.00 & 0.00 & 1.00 & $-29.72 * * *$ \\
\hline Uniform Inv. Adviser Law (65) & $13,438,634$ & 0.16 & 0.36 & 0.00 & 0.00 & 0.00 & 57,189 & 0.48 & 0.50 & 0.00 & 0.00 & 1.00 & $-154.27 * * *$ \\
\hline General Sec. Principal (24) & $13,438,634$ & 0.12 & 0.32 & 0.00 & 0.00 & 0.00 & 57,189 & 0.26 & 0.44 & 0.00 & 0.00 & 1.00 & $-76.48 * * *$ \\
\hline Observations & $13,438,634$ & & & & & & 57,189 & & & & & & $13,495,823$ \\
\hline
\end{tabular}


Table 1. Panel B. This table provides summary statistics for firms from the BrokerCheck data. The BrokerCheck data include a balanced panel of 8,000 firms from 2007 to 2017. Firms dually registered as investment advisers were matched to Form ADV data spanning from 2007 to 2015. As in Panel A, we divide firms into two groups according to whether any FINRA-registered brokers employed by the firm filed a request for expungement between 2007 and 2017. The final column corresponds to a t-test for equality of means between the two groups. Statistical significance of $10 \%, 5 \%$, and $1 \%$ is represented by *,**, and ***, respectively.

\begin{tabular}{|c|c|c|c|c|c|c|c|c|c|c|c|}
\hline & \multicolumn{5}{|c|}{ Firms With Expungement Attempts } & \multicolumn{5}{|c|}{ Firms Without Expungement Attempts } & \multirow{2}{*}{$\frac{\mathrm{t} \text {-test }}{\mathrm{t}}$} \\
\hline & Obs. & $\begin{array}{c}\text { No. } \\
\text { Firms }\end{array}$ & Mean & Std. Dev. & Median & Obs. & $\begin{array}{l}\text { No. } \\
\text { Firms }\end{array}$ & Mean & Std. Dev. & Median & \\
\hline \multicolumn{12}{|l|}{ BrokerCheck Data } \\
\hline Investment Advisor & 1,530 & 699 & 0.58 & 0.49 & 1.00 & 51,283 & 7,120 & 0.19 & 0.39 & 0.00 & $30.70 * * *$ \\
\hline Affiliated w/ Fin. Inst. & 1,530 & 699 & 0.66 & 0.47 & 1.00 & 51,283 & 7,120 & 0.38 & 0.49 & 0.00 & $22.51 * * *$ \\
\hline Firm Age & 1,530 & 699 & 28.14 & 17.97 & 23.00 & 51,241 & 7,103 & 21.24 & 12.81 & 18.00 & $14.90 * * *$ \\
\hline Num. Business Lines & 1,530 & 699 & 10.19 & 7.49 & 12.00 & 51,279 & 7,118 & 3.75 & 4.42 & 2.00 & $33.40 * * *$ \\
\hline Num. of Advisers & 1,530 & 699 & 2352.51 & 5307.55 & 379.50 & 51,283 & 7,120 & 81.50 & 583.58 & 9.00 & $16.73 * * *$ \\
\hline Firm Employee Misconduct (flow in one year) & 1,530 & 699 & 0.03 & 0.06 & 0.01 & 51,283 & 7,120 & 0.01 & 0.05 & 0.00 & $12.32 * * *$ \\
\hline Firm Employee Misconduct (stock - including pre-2007) & 1,530 & 699 & 0.20 & 0.16 & 0.15 & 51,283 & 7,120 & 0.13 & 0.20 & 0.04 & $17.03 * * *$ \\
\hline Active & 1,530 & 699 & 0.74 & 0.44 & 1.00 & 51,283 & 7,120 & 0.67 & 0.47 & 1.00 & $6.46^{* * *}$ \\
\hline Num. of States & 1,530 & 699 & 36.18 & 23.27 & 52.00 & 51,279 & 7,118 & 15.44 & 20.13 & 3.00 & $34.47 * * *$ \\
\hline Expelled Firms & 1,530 & 699 & 0.06 & 0.24 & 0.00 & 51,283 & 7,120 & 0.02 & 0.15 & 0.00 & $6.46 * * *$ \\
\hline \multicolumn{12}{|l|}{ Form ADV Data } \\
\hline Services Retail Clients & 682 & 236 & 0.95 & 0.22 & 1.00 & 3,554 & 714 & 0.83 & 0.38 & 1.00 & $11.40 * * *$ \\
\hline Number of Accounts & 646 & 226 & 99714.72 & 269510.15 & 8032.50 & 3,343 & 674 & 3984.89 & 18410.80 & 541.00 & $9.02 * * *$ \\
\hline Assets Under Management ( $\$$ millions) & 646 & 226 & 25154.62 & 67998.62 & 1871.48 & 3,343 & 674 & 2226.02 & 9543.29 & 237.02 & $8.55^{* * *}$ \\
\hline \multicolumn{12}{|l|}{ Compensation/ Fee Structure } \\
\hline Hourly & 682 & 236 & 0.57 & 0.50 & 1.00 & 3,554 & 714 & 0.45 & 0.50 & 0.00 & $6.02 * * *$ \\
\hline Fixed Fee & 682 & 236 & 0.80 & 0.40 & 1.00 & 3,554 & 714 & 0.56 & 0.50 & 1.00 & $13.65^{* * *}$ \\
\hline Commission & 682 & 236 & 0.56 & 0.50 & 1.00 & 3,554 & 714 & 0.43 & 0.50 & 0.00 & $6.10 * * *$ \\
\hline Performance & 682 & 236 & 0.12 & 0.33 & 0.00 & 3,554 & 714 & 0.11 & 0.31 & 0.00 & 1.05 \\
\hline Observations & 1,530 & & & & & 51,283 & & & & & 52,813 \\
\hline
\end{tabular}


Table 2. This table provides summary statistics for the Expungement Data. Observations are presented by broker even if there were multiple brokers in the same arbitration award. We divide observations into two groups - those in which expungement was granted and those in which expungement was denied. The final column corresponds to a t-test for equality of means between the two groups. Statistical significance of $10 \%, 5 \%$, and $1 \%$ is represented by *,**, and ***, respectively.

\begin{tabular}{|c|c|c|c|c|c|c|c|c|c|c|c|c|c|}
\hline & \multicolumn{4}{|c|}{ All Expungements } & \multicolumn{4}{|c|}{ Successful } & \multicolumn{4}{|c|}{ Unsuccessful } & \multirow{2}{*}{$\frac{\mathrm{t} \text {-test }}{\mathrm{t}}$} \\
\hline & Obs. & Mean & Std. Dev. & Median & Obs. & Mean & Std. Dev. & Median & Obs. & Mean & Std. Dev. & Median & \\
\hline \multicolumn{14}{|l|}{ Broker Characteristics } \\
\hline Barred & 5,640 & 0.019 & 0.14 & 0.000 & 3,955 & 0.008 & 0.09 & 0.000 & 1,685 & 0.044 & 0.20 & 0.000 & $-9.13 * * *$ \\
\hline Prior Successful Expungement & 5,640 & 0.073 & 0.26 & 0.000 & 3,955 & 0.083 & 0.28 & 0.000 & 1,685 & 0.050 & 0.22 & 0.000 & $4.29 * * *$ \\
\hline Employed in FINRA Registered Capacity & 5,640 & 0.879 & 0.33 & 1.000 & 3,955 & 0.911 & 0.29 & 1.000 & 1,685 & 0.803 & 0.40 & 1.000 & $11.47 * * *$ \\
\hline \multicolumn{14}{|l|}{ Gender } \\
\hline Female & 5,490 & 0.131 & 0.34 & 0.000 & 3,846 & 0.139 & 0.35 & 0.000 & 1,644 & 0.113 & 0.32 & 0.000 & $2.70 * *$ \\
\hline \multicolumn{14}{|l|}{ Ethnicity } \\
\hline White & 6,055 & 0.000 & 0.00 & 0.000 & 4,268 & 0.000 & 0.00 & 0.000 & 1,787 & 0.000 & 0.00 & 0.000 & . \\
\hline Black & 6,055 & 0.002 & 0.05 & 0.000 & 4,268 & 0.002 & 0.05 & 0.000 & 1,787 & 0.002 & 0.05 & 0.000 & 0.08 \\
\hline Asian Pacific Islander & 6,055 & 0.019 & 0.14 & 0.000 & 4,268 & 0.016 & 0.13 & 0.000 & 1,787 & 0.028 & 0.16 & 0.000 & $-3.10^{* *}$ \\
\hline Hispanic & 6,055 & 0.045 & 0.21 & 0.000 & 4,268 & 0.044 & 0.20 & 0.000 & 1,787 & 0.048 & 0.21 & 0.000 & -0.64 \\
\hline American Indian and Alaska Native & 6,055 & 0.000 & 0.00 & 0.000 & 4,268 & 0.000 & 0.00 & 0.000 & 1,787 & 0.000 & 0.00 & 0.000 & . \\
\hline \multicolumn{14}{|l|}{ Contribute Republican } \\
\hline Contribute Republican & 6,055 & 2623.128 & 92594.18 & 0.000 & 4,268 & 2539.990 & 90151.66 & 0.000 & 1,787 & 2821.694 & 98208.15 & 0.000 & -0.11 \\
\hline Contribute Democrat & 6,055 & 163.915 & 1299.19 & 0.000 & 4,268 & 145.908 & 1112.81 & 0.000 & 1,787 & 206.924 & 1661.40 & 0.000 & -1.67 \\
\hline Contribute Both & 6,055 & 0.037 & 0.19 & 0.000 & 4,268 & 0.037 & 0.19 & 0.000 & 1,787 & 0.039 & 0.19 & 0.000 & -0.49 \\
\hline Contribute Neither Party & 6,055 & 0.782 & 0.41 & 1.000 & 4,268 & 0.780 & 0.41 & 1.000 & 1,787 & 0.785 & 0.41 & 1.000 & -0.42 \\
\hline Total Sum Contributed & 6,055 & 2787.044 & 93115.53 & 0.000 & 4,268 & 2685.898 & 90656.27 & 0.000 & 1,787 & 3028.618 & 98767.53 & 0.000 & -0.13 \\
\hline Observations & 6055 & & & & 4268 & & & & 1787 & & & & 6055 \\
\hline
\end{tabular}


Table 3. Panel A. This table examines the determinants of misconduct. The dependent variable is a dummy for whether there was a new allegation of misconduct in a particular year. In Column (1), the variable of interest is a dummy for whether the broker had a misconduct in any year prior to the new misconduct. In Column (2), the variable of interest is a dummy for whether the broker had a successful expungement in any year prior to the new misconduct. In Column (3), the variable of interest is a dummy for whether the broker had an unsuccessful expungement in any year prior to the new misconduct. All models include year-county-firm fixed effects and control for the broker's years of experience, gender, race, total qualifications, and whether the broker has passed the following exams: Series 65 or $66,24,6$ and 7. Standard errors are in parentheses and are clustered by firm. Statistical significance of $10 \%, 5 \%$, and $1 \%$ is represented by $* * *$, and $* * *$, respectively.

\begin{tabular}{|c|c|c|c|c|c|c|}
\hline & (1) & $(2)$ & (3) & $(4)$ & $(5)$ & $(6)$ \\
\hline Prior Misconduct & $\begin{array}{c}0.044 * * * \\
(13.456)\end{array}$ & & & $\begin{array}{c}0.044 * * * \\
(13.433)\end{array}$ & $\begin{array}{c}0.043 * * * \\
(11.891)\end{array}$ & \\
\hline Prior Successful Expungement & & $\begin{array}{c}0.018 * * * \\
(4.309)\end{array}$ & & $\begin{array}{c}0.011 * * * \\
(3.695)\end{array}$ & & $\begin{array}{c}0.014 * * * \\
(3.653)\end{array}$ \\
\hline Prior Unsuccessful Expungement & & & $\begin{array}{c}0.086 * * * \\
(23.830)\end{array}$ & & $\begin{array}{c}0.072 * * * \\
(14.772)\end{array}$ & $\begin{array}{c}0.085 * * * \\
(23.842)\end{array}$ \\
\hline Constant & $\begin{array}{c}0.002 * * * \\
(3.956)\end{array}$ & $\begin{array}{c}0.002 * * * \\
(2.700)\end{array}$ & $\begin{array}{c}0.002 * * * \\
(2.737)\end{array}$ & $\begin{array}{c}0.002 * * * \\
(3.966)\end{array}$ & $\begin{array}{c}0.002 * * * \\
(3.938)\end{array}$ & $\begin{array}{c}0.002 * * * \\
(2.751)\end{array}$ \\
\hline $\begin{array}{l}\text { Controls } \\
\text { Year X County X Firm FE } \\
\text { Observations } \\
\text { Adj. R-Square } \\
\text { F_diff }\end{array}$ & $\begin{array}{c}\text { Yes } \\
\text { Yes } \\
12,290,564 \\
0.104\end{array}$ & $\begin{array}{c}\text { Yes } \\
\text { Yes } \\
12,290,564 \\
0.096\end{array}$ & $\begin{array}{c}\text { Yes } \\
\text { Yes } \\
12,290,564 \\
0.098\end{array}$ & $\begin{array}{c}\text { Yes } \\
\text { Yes } \\
12,290,564 \\
0.104 \\
290.543\end{array}$ & $\begin{array}{c}\text { Yes } \\
\text { Yes } \\
12,290,564 \\
0.105 \\
15.028\end{array}$ & $\begin{array}{c}\text { Yes } \\
\text { Yes } \\
12,290,564 \\
0.098 \\
200.460\end{array}$ \\
\hline
\end{tabular}


Table 3. Panel B. This table examines cross-sectional variation in the determinants of misconduct. The dependent and independent variables are as per Panel A with additional interactions for gender and race. All models control for the variables noted in Panel A. Standard errors are clustered by firm. Statistical significance of $10 \%, 5 \%$, and $1 \%$ is represented by $* * *$, and $* * *$, respectively.

\begin{tabular}{|c|c|c|c|c|c|c|}
\hline & $(1)$ & $(2)$ & (3) & $(4)$ & (5) & $(6)$ \\
\hline Prior Misconduct & $\begin{array}{c}0.047 * * * \\
(12.149)\end{array}$ & & & $\begin{array}{c}0.044 * * * \\
(12.550)\end{array}$ & & \\
\hline Female & $\begin{array}{c}-0.002 * * * \\
(-3.490)\end{array}$ & $\begin{array}{c}-0.003 * * * \\
(-5.494)\end{array}$ & $\begin{array}{c}-0.003 * * * \\
(-5.573)\end{array}$ & & & \\
\hline Prior Misconduct X Female & $\begin{array}{c}-0.018 * * * \\
(-5.989)\end{array}$ & & & & & \\
\hline Prior Successful Expungement & & $\begin{array}{c}0.019 * * * \\
(4.072)\end{array}$ & & & $\begin{array}{c}0.016^{* * * *} \\
(4.217)\end{array}$ & \\
\hline Prior Successful Expungement X Female & & $\begin{array}{c}-0.006 \\
(-1.325)\end{array}$ & & & & \\
\hline Prior Unsuccessful Expungement & & & $\begin{array}{c}0.088 * * * \\
(21.968)\end{array}$ & & & $\begin{array}{c}0.086 * * * \\
(23.588)\end{array}$ \\
\hline Prior Unsuccessful Expungement X Female & & & $\begin{array}{c}-0.018 * * \\
(-2.322)\end{array}$ & & & \\
\hline Non-White & & & & $\begin{array}{c}0.000 \\
(1.265)\end{array}$ & $\begin{array}{l}0.000^{*} \\
(1.701)\end{array}$ & $\begin{array}{l}0.000^{*} \\
(1.680)\end{array}$ \\
\hline Prior Misconduct X Non-White & & & & $\begin{array}{c}0.003 \\
(0.571)\end{array}$ & & \\
\hline Prior Successful Expungement X Non-White & & & & & $\begin{array}{c}0.047^{* * *} \\
(2.458)\end{array}$ & \\
\hline Prior Unsuccessful Expungement X Non-White & & & & & & $\begin{array}{c}0.010 \\
(1.012)\end{array}$ \\
\hline Constant & $\begin{array}{c}0.002 \text { **** } \\
(3.706)\end{array}$ & $\begin{array}{c}0.002 * * * \\
(2.728)\end{array}$ & $\begin{array}{c}0.002 * * * \\
(2.765)\end{array}$ & $\begin{array}{c}0.001 * * * \\
(3.914)\end{array}$ & $\begin{array}{l}0.001 * \\
(1.920)\end{array}$ & $\begin{array}{c}0.001 * * \\
(2.014)\end{array}$ \\
\hline Controls & Yes & Yes & Yes & Yes & Yes & Yes \\
\hline Year X County X Firm FE & Yes & Yes & Yes & Yes & Yes & Yes \\
\hline Observations & $12,290,564$ & $12,290,564$ & $12,290,564$ & $13,005,949$ & $13,005,949$ & $13,005,949$ \\
\hline Adj. R-Square & 0.104 & 0.096 & 0.098 & 0.103 & 0.095 & 0.097 \\
\hline
\end{tabular}


Table 3. Panel C. This table examines the determinants of misconduct based on arbitration characteristics. The dependent variable is as per Panel A, and unsuccessful expungements are dropped from the sample. In Columns (1)-(3), the variables of interest are dummies for the FINRA Rule 2080 justification provided in expungement award. In Column (4), the expungement awards are partitioned by whether there was a settlement. In Column (5), the expungement awards are partitioned by whether the request was opposed by the customer. In Column (6), the variable of interest is the log of the settlement amount (if disclosed) from the expungement arbitration. All models control for the variables noted in Panel A. Standard errors are clustered by firm. Statistical significance of 10\%, 5\%, and 1\% is represented by $* * *$, and ${ }^{* * *}$, respectively.

\begin{tabular}{|c|c|c|c|c|c|c|c|}
\hline & (1) & (2) & (3) & (4) & $(5)$ & (6) & (7) \\
\hline False & $\begin{array}{c}0.025 * * * \\
(4.04)\end{array}$ & & & & & & \\
\hline Erroneous & & $\begin{array}{c}0.026 * * * \\
(5.85)\end{array}$ & & & & & \\
\hline Not Involved & & & $\begin{array}{c}0.038^{* * *} \\
(5.17)\end{array}$ & & & & \\
\hline Truly Erroneous & & & & $\begin{array}{c}0.029 * * * \\
(2.86)\end{array}$ & & & \\
\hline Expungement with Settlement & & & & & $\begin{array}{c}0.032 * * * \\
(6.29)\end{array}$ & & \\
\hline Expungement without Settlement & & & & & $\begin{array}{c}0.025 * * * \\
(3.33)\end{array}$ & & \\
\hline Expungement with Customer Opposition & & & & & & $\begin{array}{c}0.029 * * * \\
(3.87)\end{array}$ & \\
\hline Expungement without Customer Opposition & & & & & & $\begin{array}{c}0.032 * * * \\
(5.74)\end{array}$ & \\
\hline Log Settlement & & & & & & & $\begin{array}{c}0.090 * * * \\
(126.71)\end{array}$ \\
\hline Controls & Yes & Yes & Yes & Yes & Yes & Yes & Yes \\
\hline Year X County X Firm FE & Yes & Yes & Yes & Yes & Yes & Yes & Yes \\
\hline Observations & $11,749,907$ & $11,749,907$ & $11,749,907$ & $11,749,907$ & $11,749,907$ & $11,749,907$ & $11,749,907$ \\
\hline Adj. R-Square & 0.058 & 0.058 & 0.058 & 0.058 & 0.058 & 0.058 & 0.332 \\
\hline
\end{tabular}


Table 4. This table examines who files for expungement at the broker level. The sample includes only brokers eligible to file for expungement - that is, brokers with an allegation of misconduct. The dependent variable in Columns (1) and (2) is a dummy for whether the broker filed an expungement request in any year during our sample period. The dependent variable in Columns (3) and (4) is whether the broker filed an expungement request in a particular year. All models control for the variables noted in Table 3. Standard errors are clustered by broker. Statistical significance of $10 \%, 5 \%$, and $1 \%$ is represented by $* * *$, and $* * *$, respectively.

\begin{tabular}{|c|c|c|c|c|}
\hline & \multicolumn{2}{|c|}{ One Obs. } & \multicolumn{2}{|c|}{ Full } \\
\hline & $(1)$ & $(2)$ & (3) & (4) \\
\hline Total Number of Disclosures 2007-2017 & & $\begin{array}{c}0.001 \\
(1.499)\end{array}$ & & $\begin{array}{c}-0.000 \\
(-0.501)\end{array}$ \\
\hline \multicolumn{5}{|l|}{ Broker Characteristics } \\
\hline Female & $\begin{array}{c}0.010 * * * \\
(4.764)\end{array}$ & $\begin{array}{c}0.010 * * * \\
(4.881)\end{array}$ & $\begin{array}{c}0.006^{* * * *} \\
(3.548)\end{array}$ & $\begin{array}{c}0.005^{* * * *} * \\
(3.500)\end{array}$ \\
\hline Non-White & $\begin{array}{l}0.005 * \\
(1.936)\end{array}$ & $\begin{array}{l}0.005 * \\
(1.832)\end{array}$ & $\begin{array}{c}0.001 \\
(0.816)\end{array}$ & $\begin{array}{c}0.002 \\
(0.879)\end{array}$ \\
\hline Experience / 10 & $\begin{array}{c}0.000 \\
(0.203)\end{array}$ & $\begin{array}{c}-0.000 \\
(-0.236)\end{array}$ & $\begin{array}{c}-0.002 * * * \\
(-4.061)\end{array}$ & $\begin{array}{c}-0.002 * * * \\
(-3.887)\end{array}$ \\
\hline Qualifications & $\begin{array}{c}0.002 \\
(0.369)\end{array}$ & $\begin{array}{c}0.002 \\
(0.376)\end{array}$ & $\begin{array}{c}0.003 \\
(0.715)\end{array}$ & $\begin{array}{c}0.003 \\
(0.713)\end{array}$ \\
\hline S65/S66 & $\begin{array}{c}0.003 \\
(0.377)\end{array}$ & $\begin{array}{c}0.003 \\
(0.352)\end{array}$ & $\begin{array}{c}0.000 \\
(0.081)\end{array}$ & $\begin{array}{c}0.000 \\
(0.090)\end{array}$ \\
\hline Uniform Sec. Agent St. Law (63) & $\begin{array}{c}0.002 \\
(0.321)\end{array}$ & $\begin{array}{c}0.002 \\
(0.297)\end{array}$ & $\begin{array}{c}0.000 \\
(0.082)\end{array}$ & $\begin{array}{c}0.000 \\
(0.090)\end{array}$ \\
\hline General Sec. Principal (24) & $\begin{array}{c}0.011 \\
(1.561)\end{array}$ & $\begin{array}{c}0.011 \\
(1.554)\end{array}$ & $\begin{array}{c}0.004 \\
(0.957)\end{array}$ & $\begin{array}{c}0.004 \\
(0.958)\end{array}$ \\
\hline General Sec. Rep (7) & $\begin{array}{c}0.017 * * \\
(2.452)\end{array}$ & $\begin{array}{c}0.017 * * \\
(2.409)\end{array}$ & $\begin{array}{c}0.003 \\
(0.608)\end{array}$ & $\begin{array}{c}0.003 \\
(0.621)\end{array}$ \\
\hline Inv. Co. Products (Rep). (6) & $\begin{array}{c}-0.017 * * * \\
(-8.962)\end{array}$ & $\begin{array}{c}-0.017 * * * \\
(-8.997)\end{array}$ & $\begin{array}{c}-0.009 * * * \\
(-7.185)\end{array}$ & $\begin{array}{c}-0.009 * * * \\
(-7.180)\end{array}$ \\
\hline Other Qualifications & $\begin{array}{c}0.078 * * * \\
(8.610)\end{array}$ & $\begin{array}{c}0.079 * * * \\
(8.705)\end{array}$ & $\begin{array}{c}0.047 * * * \\
(7.940)\end{array}$ & $\begin{array}{c}0.047^{* * * *} * \\
(7.908)\end{array}$ \\
\hline Employed in FINRA Registered Capacity & $\begin{array}{c}0.007 * * * \\
(3.909)\end{array}$ & $\begin{array}{c}0.007 * * * \\
(4.042)\end{array}$ & $\begin{array}{c}0.010^{* * * *} \\
(8.272)\end{array}$ & $\begin{array}{c}0.010^{* * * *} * \\
(8.192)\end{array}$ \\
\hline Barred & $\begin{array}{c}-0.008 * * * \\
(-3.427)\end{array}$ & $\begin{array}{c}-0.010 * * * \\
(-3.987)\end{array}$ & $\begin{array}{c}-0.004 * * * \\
(-2.701)\end{array}$ & $\begin{array}{c}-0.004 * * \\
(-2.071)\end{array}$ \\
\hline Retail & $\begin{array}{c}0.039 * * * \\
(16.557)\end{array}$ & $\begin{array}{c}0.039 * * * \\
(16.601)\end{array}$ & $\begin{array}{c}0.015^{* * * *} \\
(10.261)\end{array}$ & $\begin{array}{c}0.015^{* * * *} * \\
(10.258)\end{array}$ \\
\hline \multicolumn{5}{|l|}{ Firm Characteristics } \\
\hline Taping/Disciplined Firm & $\begin{array}{c}0.068 * * * \\
(6.766)\end{array}$ & $\begin{array}{c}0.067 * * * \\
(6.633)\end{array}$ & $\begin{array}{c}0.023 * * * \\
(2.605)\end{array}$ & $\begin{array}{c}0.023 * * * \\
(2.628)\end{array}$ \\
\hline Investment Advisor & $\begin{array}{c}0.004 \\
(1.619)\end{array}$ & $\begin{array}{c}0.004 \\
(1.620)\end{array}$ & $\begin{array}{c}-0.002 \\
(-1.082)\end{array}$ & $\begin{array}{c}-0.002 \\
(-1.093)\end{array}$ \\
\hline Num. Brokers & $\begin{array}{c}-0.000 * * * \\
(-5.956)\end{array}$ & $\begin{array}{c}-0.000 * * * \\
(-5.875)\end{array}$ & $\begin{array}{c}-0.000 * * * \\
(-23.180)\end{array}$ & $\begin{array}{c}-0.000 * * * \\
(-23.192)\end{array}$ \\
\hline Num. Retail Brokers & $\begin{array}{c}0.000^{* * * *} \\
(10.491)\end{array}$ & $\begin{array}{c}0.000 * * * \\
(10.487)\end{array}$ & $\begin{array}{c}0.000 * * * \\
(24.332)\end{array}$ & $\begin{array}{c}0.000^{* * * *} * \\
(24.333)\end{array}$ \\
\hline Constant & $\begin{array}{c}-0.000 \\
(-0.142)\end{array}$ & $\begin{array}{c}-0.001 \\
(-0.536)\end{array}$ & $\begin{array}{c}0.007 * * * \\
(4.087)\end{array}$ & $\begin{array}{c}0.007^{*} * * \\
(4.089)\end{array}$ \\
\hline $\begin{array}{l}\text { Controls } \\
\text { Observations } \\
\text { Adj. R-Square }\end{array}$ & $\begin{array}{c}\text { Yes } \\
94,702 \\
0.032\end{array}$ & $\begin{array}{c}\text { Yes } \\
94,702 \\
0.032\end{array}$ & $\begin{array}{c}\text { Yes } \\
731,420 \\
0.019\end{array}$ & $\begin{array}{c}\text { Yes } \\
731,420 \\
0.019\end{array}$ \\
\hline
\end{tabular}


Table 5. Panel A. This table examines the determinants of a successful expungement. The dependent variable is equal to 1 if the expungement was successful. All models control for the broker characteristics described in Table 3 and include fixed effects for the arbitration hearing site, year and firm. Standard errors are clustered by broker. Statistical significance of $10 \%, 5 \%$, and $1 \%$ is represented by $*, * *$, and $* * *$, respectively.

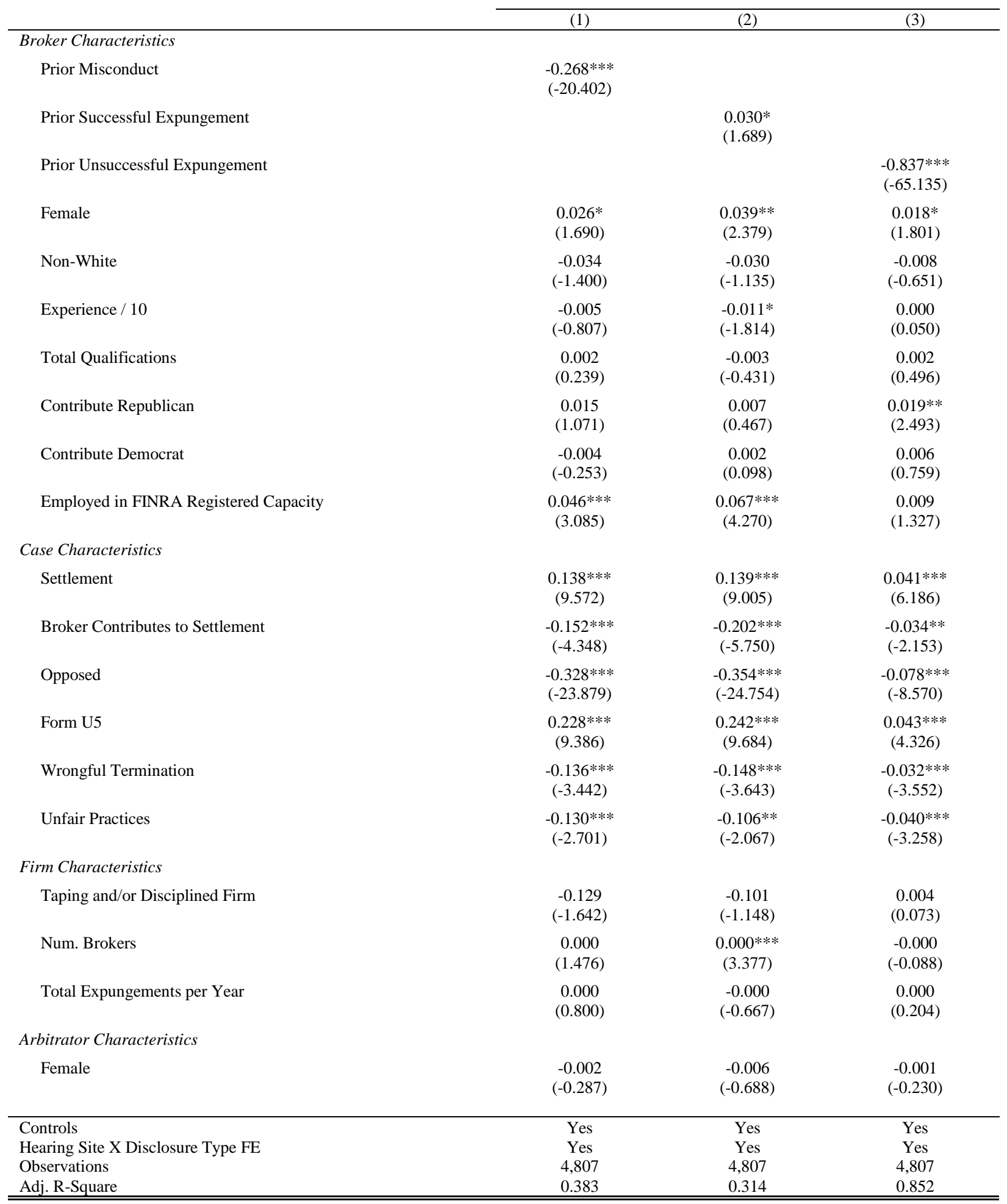


Table 5. Panel B. This table examines the determinants of a successful "erroneous" expungement. The sample includes only successful expungements, and the dependent variable is equal to 1 if the broker committed future misconduct. All models control for the broker characteristics described in Table 3 and include fixed effects for the arbitration hearing site, year and firm. Standard errors are clustered by broker. Statistical significance of 10\%, 5\%, and $1 \%$ is represented by $*, * *$, and $* * *$, respectively.

\begin{tabular}{|c|c|c|}
\hline & & \\
\hline \multirow{2}{*}{\multicolumn{3}{|c|}{ Broker Characteristics }} \\
\hline & & \\
\hline Prior Misconduct & $\begin{array}{c}-0.056^{* * *} \\
(-5.481)\end{array}$ & \\
\hline Prior Unsuccessful Expungement & & $\begin{array}{c}-0.534 * * * \\
(-12.059)\end{array}$ \\
\hline Female & $\begin{array}{c}0.006 \\
(0.946)\end{array}$ & $\begin{array}{l}0.009^{*} \\
(1.714)\end{array}$ \\
\hline Non-White & $\begin{array}{c}-0.000 \\
(-0.014)\end{array}$ & $\begin{array}{c}0.011 \\
(1.181)\end{array}$ \\
\hline Experience / 10 & $\begin{array}{c}0.002 \\
(0.722)\end{array}$ & $\begin{array}{c}0.002 \\
(0.940)\end{array}$ \\
\hline Total Qualifications & $\begin{array}{c}-0.003 \\
(-0.730)\end{array}$ & $\begin{array}{c}0.001 \\
(0.548)\end{array}$ \\
\hline Contribute Republican & $\begin{array}{c}0.003 \\
(0.363)\end{array}$ & $\begin{array}{l}0.010^{*} \\
(1.861)\end{array}$ \\
\hline Contribute Democrat & $\begin{array}{c}0.000 \\
(0.024)\end{array}$ & $\begin{array}{c}0.005 \\
(0.684)\end{array}$ \\
\hline Employed in FINRA Registered Capacity & $\begin{array}{c}-0.001 \\
(-0.166)\end{array}$ & $\begin{array}{c}-0.005 \\
(-0.924)\end{array}$ \\
\hline \multicolumn{3}{|l|}{ Case Characteristics } \\
\hline Settlement & $\begin{array}{c}0.023 * * * \\
(2.677)\end{array}$ & $\begin{array}{c}0.018 * * * \\
(3.042)\end{array}$ \\
\hline Broker Contributes to Settlement & $\begin{array}{c}-0.021 \\
(-0.708)\end{array}$ & $\begin{array}{c}-0.002 \\
(-0.074)\end{array}$ \\
\hline Opposed & $\begin{array}{c}-0.044 * * * \\
(-5.554)\end{array}$ & $\begin{array}{c}-0.020 * * * \\
(-3.901)\end{array}$ \\
\hline Form U5 & $\begin{array}{c}0.039 * * * \\
(5.792)\end{array}$ & $\begin{array}{c}0.019 * * * \\
(2.912)\end{array}$ \\
\hline Wrongful Termination & $\begin{array}{c}0.005 \\
(0.660)\end{array}$ & $\begin{array}{c}-0.002 \\
(-0.386)\end{array}$ \\
\hline Unfair Practices & $\begin{array}{c}-0.001 \\
(-0.138)\end{array}$ & $\begin{array}{c}-0.001 \\
(-0.080)\end{array}$ \\
\hline \multicolumn{3}{|l|}{ Firm Characteristics } \\
\hline Taping and/or Disciplined Firm & $\begin{array}{c}0.049 * * * \\
(3.181)\end{array}$ & $\begin{array}{c}0.103 \\
(1.570)\end{array}$ \\
\hline Num. Brokers & $\begin{array}{c}0.000 \\
(1.183)\end{array}$ & $\begin{array}{l}0.000 \\
(0.352)\end{array}$ \\
\hline Total Expungements per Year & $\begin{array}{c}-0.000 \\
(-1.047)\end{array}$ & $\begin{array}{c}-0.000 \\
(-0.436)\end{array}$ \\
\hline \multicolumn{3}{|l|}{ Arbitrator Characteristics } \\
\hline Female & $\begin{array}{c}-0.005 \\
(-1.407)\end{array}$ & $\begin{array}{c}-0.003 \\
(-1.057)\end{array}$ \\
\hline Controls & Yes & \\
\hline Hearing Site X Disclosure Type FE & Yes & \\
\hline Observations & 3,279 & 3,279 \\
\hline Adj. R-Square & 0.081 & 0.463 \\
\hline
\end{tabular}


Table 6. This table analyzes whether expungement can predict recidivism. The dependent variable is equal to 1 if a broker has multiple allegations of misconduct, including expunged misconduct, in at least two different years between 2007 and 2017. All models control for the variables noted in Table 3. Standard errors are clustered by broker. Statistical significance of $10 \%, 5 \%$, and $1 \%$ is represented by $*$, **, and $* * *$, respectively.

\begin{tabular}{|c|c|c|c|c|c|c|c|c|c|c|c|c|}
\hline & (1) & (2) & (3) & (4) & (5) & (6) & $(7)$ & $(8)$ & (9) & $(10)$ & $(11)$ & (12) \\
\hline Expungement & $\begin{array}{l}0.175^{* * *} * \\
(18.227)\end{array}$ & & & $\begin{array}{l}0.185 * * * \\
(17.716)\end{array}$ & & & $\begin{array}{l}0.173 * * * \\
(17.349)\end{array}$ & & & $\begin{array}{l}0.169 * * * \\
(15.907)\end{array}$ & & \\
\hline Successful Expungement & & $\begin{array}{c}0.077 * * * \\
(7.089)\end{array}$ & & & $\begin{array}{c}0.084 * * * \\
(7.046)\end{array}$ & & & $\begin{array}{c}0.074 * * * * \\
(6.623)\end{array}$ & & & $\begin{array}{c}0.070 * * * \\
(5.862)\end{array}$ & \\
\hline Unsuccessful Expungement & & & $\begin{array}{l}0.420 * * * \\
(29.068)\end{array}$ & & & $\begin{array}{l}0.422 * * * \\
(27.692)\end{array}$ & & & $\begin{array}{l}0.423 * * * \\
(27.915)\end{array}$ & & & $\begin{array}{l}0.423 * * * \\
(26.443)\end{array}$ \\
\hline Female & & & & $\begin{array}{l}-0.062 * * * \\
(-9.057)\end{array}$ & $\begin{array}{l}-0.065 * * * \\
(-9.513)\end{array}$ & $\begin{array}{l}-0.064 * * * \\
(-9.681)\end{array}$ & & & & & & \\
\hline Expungement X Female & & & & $\begin{array}{l}-0.062 * * \\
(-2.455)\end{array}$ & & & & & & & & \\
\hline Successful Expungement X & & & & & & & & & & & & \\
\hline Female & & & & & $\begin{array}{c}-0.032 \\
(-1.161)\end{array}$ & & & & & & & \\
\hline Unsuccessful Expungement X & & & & & & & & & & & & \\
\hline Female & & & & & & $\begin{array}{c}-0.040 \\
(-0.828)\end{array}$ & & & & & & \\
\hline Non-White & & & & & & & $\begin{array}{c}0.012 \\
(1.390)\end{array}$ & $\begin{array}{c}0.010 \\
(1.248)\end{array}$ & $\begin{array}{c}0.011 \\
(1.394)\end{array}$ & & & \\
\hline Expungement X Non-White & & & & & & & $\begin{array}{c}0.039 \\
(1.098)\end{array}$ & & & & & \\
\hline Successful Expungement X & & & & & & & & & & & & \\
\hline Non-White & & & & & & & & $\begin{array}{c}0.049 \\
(1.140)\end{array}$ & & & & \\
\hline Unsuccessful Expungement $\mathrm{X}$ & & & & & & & & & & & & \\
\hline Non-White & & & & & & & & & $\begin{array}{c}-0.037 \\
(-0.771)\end{array}$ & & & \\
\hline Contribute & & & & & & & & & & $\begin{array}{c}0.413 * * * \\
(8.692)\end{array}$ & $\begin{array}{c}0.352 * * * \\
(12.789)\end{array}$ & $\begin{array}{c}0.134 * * * \\
(6.553)\end{array}$ \\
\hline Expungement $X$ Contribute & & & & & & & & & & $\begin{array}{l}-0.374 * * * \\
(-7.216)\end{array}$ & & \\
\hline Successful Expungement X & & & & & & & & & & & & \\
\hline Contribute & & & & & & & & & & & $\begin{array}{l}-0.292 * * * \\
(-8.055)\end{array}$ & \\
\hline $\begin{array}{l}\text { Unsuccessful Expungement X } \\
\text { Contribute }\end{array}$ & & & & & & & & & & & & $\begin{array}{c}-0.149 * * \\
(-3.880)\end{array}$ \\
\hline Controls & Yes & Yes & Yes & Yes & Yes & Yes & Yes & Yes & Yes & Yes & Yes & Yes \\
\hline Year X County X Firm FE & Yes & Yes & Yes & Yes & Yes & Yes & Yes & Yes & Yes & Yes & Yes & Yes \\
\hline Observations & 37,264 & 37,264 & 37,264 & 35,408 & 35,408 & 35,408 & 37,264 & 37,264 & 37,264 & 37,264 & 37,264 & 37,264 \\
\hline Adj. R-Square & 0.100 & 0.090 & 0.116 & 0.102 & 0.091 & 0.118 & 0.100 & 0.090 & 0.116 & 0.102 & 0.094 & 0.117 \\
\hline
\end{tabular}


Table 7. Panel A. This table analyzes the labor market consequences for brokers currently employed in a registered broker-dealer capacity. Column (1) reports the probability of a labor market outcome at time $=\mathrm{t}+1$ conditional on not having a misconduct at time $=\mathrm{t}$. Column (2) reports the probability of a labor market outcome at time $=\mathrm{t}+1$ conditional on having a misconduct at time $=\mathrm{t}$. Column (3) reports the probability of a labor market outcome at time $=\mathrm{t}+1$ conditional on an expungement at time $=\mathrm{t}$. Column (4) reports the probability of a labor market outcome at time $=\mathrm{t}+1$ conditional on a successful expungement at time $=\mathrm{t}$. Column (5) reports the probability of a labor market outcome at time $=\mathrm{t}+1$ conditional on an unsuccessful expungement at time $=\mathrm{t}$.

\begin{tabular}{|c|c|c|c|c|c|}
\hline & $\underset{t}{\text { No Misconduct at time }}=$ & Misconduct at time $=\mathrm{t}$ & $\begin{array}{l}\text { Any Expungement at } \\
\text { time }=\mathrm{t} \text { (Award Year) }\end{array}$ & $\begin{array}{l}\text { Successful Expungement } \\
\text { at time }=\mathrm{t} \text { (Award Year) }\end{array}$ & $\begin{array}{l}\text { Unsuccessful } \\
\text { Expungement at time }=\mathrm{t} \\
(\text { Award Year })\end{array}$ \\
\hline Remain with firm in $\mathrm{t}+1$ & 0.84 & 0.56 & 0.87 & 0.88 & 0.82 \\
\hline Leave firm in $\mathrm{t}+1$ & 0.16 & 0.44 & 0.13 & 0.12 & 0.18 \\
\hline Not Registered in $\mathrm{t}+1$ (conditional on leaving firm) & 0.48 & 0.64 & 0.35 & 0.29 & 0.44 \\
\hline Join different firm in $\mathrm{t}+1$ (conditional on leaving firm) & 0.52 & 0.36 & 0.65 & 0.71 & 0.56 \\
\hline
\end{tabular}


Table 7. Panel B. This table analyzes the labor market consequences for brokers not currently employed in a registered broker-dealer capacity. Column (1) reports the probability of a labor market outcome at time $=t+1$ conditional on not having a misconduct at time $=t$. Column (2) reports the probability of a labor market outcome at time $=\mathrm{t}+1$ conditional on having a misconduct at time $=\mathrm{t}$. Column (3) reports the probability of a labor market outcome at time $=\mathrm{t}+1$ conditional on an expungement at time $=\mathrm{t}$. Column (4) reports the probability of a labor market outcome at time $=\mathrm{t}+1$ conditional on a successful expungement at time $=\mathrm{t}$. Column (5) reports the probability of a labor market outcome at time $=\mathrm{t}+1$ conditional on an unsuccessful expungement at time $=\mathrm{t}$.

\begin{tabular}{|c|c|c|c|c|c|}
\hline & No Misconduct at time $=\mathrm{t}$ & Misconduct at time $=\mathrm{t}$ & $\begin{array}{l}\text { Any Expungement at time } \\
\quad=\mathrm{t}(\text { Award Year })\end{array}$ & $\begin{array}{l}\text { Successful Expungement } \\
\text { at time }=\mathrm{t} \text { (Award Year) }\end{array}$ & $\begin{array}{l}\text { Unsuccessful } \\
\text { Expungement at time }=\mathrm{t} \\
(\text { Award Year) }\end{array}$ \\
\hline Not Employed in Registered Capacity in $t+1$ & 0.80 & 0.88 & 0.78 & 0.75 & 0.81 \\
\hline Hired in Registered Capacity in $\mathrm{t}+1$ & 0.20 & 0.12 & 0.22 & 0.25 & 0.19 \\
\hline
\end{tabular}


Table 7. Panel C. This table analyzes the determinants of labor market separation for brokers who are currently registered. The dependent variable is equal to 1 if a broker is registered at a firm at time $=\mathrm{t}$ and is not registered to the same firm or is unregistered at time $=\mathrm{t}+1$. All models control for the broker characteristics described in Table 3. Standard errors are clustered by firm. Statistical significance of 10\%, 5\%, and $1 \%$ is represented by *, **, and ***, respectively.

\begin{tabular}{|c|c|c|c|c|c|c|c|c|c|}
\hline & (1) & (2) & (3) & (4) & $(5)$ & (6) & $(7)$ & $(8)$ & (9) \\
\hline Misconduct & $\begin{array}{c}0.242 * * * \\
(11.900)\end{array}$ & & & $\begin{array}{c}0.219 * * * \\
(12.739)\end{array}$ & & & $\begin{array}{c}0.228 * * * \\
(13.360)\end{array}$ & & \\
\hline Successful Expungement & & $\begin{array}{c}-0.015^{* *} \\
(-2.566)\end{array}$ & & & $\begin{array}{c}-0.017 * * * \\
(-2.697)\end{array}$ & & & $\begin{array}{c}-0.016 * * * \\
(-2.705)\end{array}$ & \\
\hline Unsuccessful Expungement & & & $\begin{array}{l}0.020 * \\
(1.748)\end{array}$ & & & $\begin{array}{c}0.019 \\
(1.633)\end{array}$ & & & $\begin{array}{c}0.024 * * \\
(2.000)\end{array}$ \\
\hline Female & & & & $\begin{array}{c}-0.014 * * * \\
(-10.410)\end{array}$ & $\begin{array}{c}-0.014 * * * \\
(-10.608)\end{array}$ & $\begin{array}{c}-0.014 * * * \\
(-10.601)\end{array}$ & & & \\
\hline Misconduct X Female & & & & $\begin{array}{c}0.113 * * * \\
(6.708)\end{array}$ & & & & & \\
\hline Successful Expungement X Female & & & & & $\begin{array}{c}0.003 \\
(0.224)\end{array}$ & & & & \\
\hline Unsuccessful Expungement X Female & & & & & & $\begin{array}{c}0.005 \\
(0.151)\end{array}$ & & & \\
\hline Non-White & & & & & & & $\begin{array}{c}-0.005 * * * \\
(-3.111)\end{array}$ & $\begin{array}{c}-0.004 * * * \\
(-2.725)\end{array}$ & $\begin{array}{c}-0.004 * * * * \\
(-2.720)\end{array}$ \\
\hline Misconduct X Non-White & & & & & & & $\begin{array}{c}0.126 * * * \\
(4.614)\end{array}$ & & \\
\hline Successful Expungement X Non-White & & & & & & & & $\begin{array}{c}0.008 \\
(0.353)\end{array}$ & \\
\hline Unsuccessful Expungement X Non-White & & & & & & & & & $\begin{array}{c}-0.044 \\
(-1.093)\end{array}$ \\
\hline Controls & Yes & Yes & Yes & Yes & Yes & Yes & Yes & Yes & Yes \\
\hline Year X County X Firm FE & Yes & Yes & Yes & Yes & Yes & Yes & Yes & Yes & Yes \\
\hline Observations & $6,617,255$ & $6,617,255$ & $6,617,255$ & $6,297,461$ & $6,297,461$ & $6,297,461$ & $6,617,255$ & $6,617,255$ & $6,617,255$ \\
\hline Adj. R-Square & 0.244 & 0.242 & 0.242 & 0.245 & 0.243 & 0.243 & 0.244 & 0.242 & 0.242 \\
\hline
\end{tabular}


Table 7. Panel D. This table analyzes the determinants that a broker will become unregistered, conditional on leaving his current role. The dependent variable is equal to 1 if a broker is a registered broker-dealer with a firm at time $=t$ and is registered as a broker-dealer with a different firm at time $=t+1$. All models control for the broker characteristics described in Table 3. Standard errors are clustered by firm. Statistical significance of 10\%, 5\%, and 1\% is represented by *,**, and ***, respectively.

\begin{tabular}{|c|c|c|c|c|c|c|c|c|c|}
\hline & $(1)$ & $(2)$ & $(3)$ & $(4)$ & $(5)$ & $(6)$ & $(7)$ & $(8)$ & $(9)$ \\
\hline Misconduct & $\begin{array}{c}-0.163 * * * \\
(-17.615)\end{array}$ & & & $\begin{array}{c}-0.160 * * * \\
(-16.789)\end{array}$ & & & $\begin{array}{c}-0.162 * * * \\
(-18.255)\end{array}$ & & \\
\hline Successful Expungement & & $\begin{array}{l}-0.000 \\
(-0.019)\end{array}$ & & & $\begin{array}{c}0.011 \\
(0.417)\end{array}$ & & & $\begin{array}{c}-0.006 \\
(-0.206)\end{array}$ & \\
\hline Unsuccessful Expungement & & & $\begin{array}{c}-0.102 * * * \\
(-3.275)\end{array}$ & & & $\begin{array}{c}-0.080 * * \\
(-2.391)\end{array}$ & & & $\begin{array}{c}-0.108 * * * \\
(-3.312)\end{array}$ \\
\hline Female & & & & $\begin{array}{c}-0.015 * * * \\
(-4.964)\end{array}$ & $\begin{array}{c}-0.014 * * * \\
(-4.647)\end{array}$ & $\begin{array}{c}-0.014 * * * * \\
(-4.647)\end{array}$ & & & \\
\hline Misconduct X Female & & & & $\begin{array}{c}-0.024 * * \\
(-2.223)\end{array}$ & & & & & \\
\hline Successful Expungement X Female & & & & & $\begin{array}{c}-0.120 \\
(-1.641)\end{array}$ & & & & \\
\hline Unsuccessful Expungement X Female & & & & & & $\begin{array}{c}-0.219 * * \\
(-2.161)\end{array}$ & & & \\
\hline Non-White & & & & & & & $\begin{array}{c}0.010 * * \\
(2.554)\end{array}$ & $\begin{array}{c}0.010^{* * *} \\
(2.462)\end{array}$ & $\begin{array}{c}0.010^{* * *} \\
(2.464)\end{array}$ \\
\hline Misconduct X Non-White & & & & & & & $\begin{array}{c}-0.009 \\
(-0.681)\end{array}$ & & \\
\hline Successful Expungement X Non-White & & & & & & & & $\begin{array}{c}0.075 \\
(1.006)\end{array}$ & \\
\hline Unsuccessful Expungement X Non-White & & & & & & & & & $\begin{array}{c}0.065 \\
(0.591)\end{array}$ \\
\hline Controls & Yes & Yes & Yes & Yes & Yes & Yes & Yes & Yes & Yes \\
\hline Year X County X Firm FE & Yes & Yes & Yes & Yes & Yes & Yes & Yes & Yes & Yes \\
\hline Observations & 984,285 & 984,285 & 984,285 & 926,315 & 926,315 & 926,315 & 984,285 & 984,285 & 984,285 \\
\hline Adj. R-Square & 0.346 & 0.345 & 0.345 & 0.346 & 0.344 & 0.344 & 0.346 & 0.345 & 0.345 \\
\hline
\end{tabular}


Table 7. Panel E. This table analyzes the determinants that a broker will become registered as a broker-dealer, conditional on the broker not being registered at time $=\mathrm{t}$. The dependent variable is equal to 1 if a broker is not registered at a firm at time $=\mathrm{t}$ and is registered as a broker-dealer with a firm at time $=\mathrm{t}+1$. All models control for the broker characteristics described in Table 3. Standard errors are clustered by firm. Statistical significance of $10 \%, 5 \%$, and $1 \%$ is represented by $*, * *$, and $* * *$, respectively.

\begin{tabular}{|c|c|c|c|c|c|c|c|c|c|}
\hline & $(1)$ & $(2)$ & (3) & $(4)$ & $(5)$ & $(6)$ & $(7)$ & $(8)$ & $(9)$ \\
\hline Misconduct & $\begin{array}{c}-0.065 * * * \\
(-30.976)\end{array}$ & & & $\begin{array}{c}-0.064 * * * * \\
(-27.851)\end{array}$ & & & $\begin{array}{c}-0.064 * * * * \\
(-28.623)\end{array}$ & & \\
\hline Successful Expungement & & $\begin{array}{c}0.004 \\
(0.206)\end{array}$ & & & $\begin{array}{c}-0.002 \\
(-0.076)\end{array}$ & & & $\begin{array}{c}0.000 \\
(0.020)\end{array}$ & \\
\hline Unsuccessful Expungement & & & $\begin{array}{c}-0.068 * * * * \\
(-5.225)\end{array}$ & & & $\begin{array}{c}-0.069 * * * \\
(-5.012)\end{array}$ & & & $\begin{array}{c}-0.071 * * * \\
(-5.171)\end{array}$ \\
\hline Female & & & & $\begin{array}{c}0.000 \\
(0.900)\end{array}$ & $\begin{array}{c}0.000 \\
(1.342)\end{array}$ & $\begin{array}{c}0.000 \\
(1.337)\end{array}$ & & & \\
\hline Misconduct X Female & & & & $\begin{array}{c}-0.007 \\
(-1.061)\end{array}$ & & & & & \\
\hline Successful Expungement X Female & & & & & $\begin{array}{c}0.032 \\
(0.646)\end{array}$ & & & & \\
\hline Unsuccessful Expungement X Female & & & & & & $\begin{array}{c}0.033 \\
(0.671)\end{array}$ & & & \\
\hline Non-White & & & & & & & $\begin{array}{c}0.003 * * * \\
(8.801)\end{array}$ & $\begin{array}{c}0.003 * * * \\
(8.745)\end{array}$ & $\begin{array}{c}0.003 * * * \\
(8.748)\end{array}$ \\
\hline Misconduct X Non-White & & & & & & & $\begin{array}{c}-0.008 \\
(-1.222)\end{array}$ & & \\
\hline Successful Expungement X Non-White & & & & & & & & $\begin{array}{c}0.047 \\
(0.599)\end{array}$ & \\
\hline Unsuccessful Expungement X Non-White & & & & & & & & & $\begin{array}{c}0.023 \\
(0.543)\end{array}$ \\
\hline Controls & Yes & Yes & Yes & Yes & Yes & Yes & Yes & Yes & Yes \\
\hline Year X County X Firm FE & Yes & Yes & Yes & Yes & Yes & Yes & Yes & Yes & Yes \\
\hline Observations & $4,706,511$ & $4,706,511$ & $4,706,511$ & $4,378,876$ & $4,378,876$ & $4,378,876$ & $4,706,511$ & $4,706,511$ & $4,706,511$ \\
\hline Adj. R-Square & 0.427 & 0.427 & 0.427 & 0.429 & 0.429 & 0.429 & 0.427 & 0.427 & 0.427 \\
\hline
\end{tabular}


Table 8. Panel A. This table ranks firms according to different expungement metrics after restricting to firms with more than 100 registered brokers. Column (1) ranks firms by the largest number of expungement requests. Column (2) ranks firms by the ratio of expungement requests to the total misconduct disclosures. Column (3) ranks firms by the ratio of expungement requests to the total number of registered brokers. Column (4) ranks firms by the ratio of expungement requests to the total number of registered retail brokers.

\begin{tabular}{|c|c|c|c|c|c|c|c|}
\hline Greatest Number of Expungements & $\mathrm{N}$ & $\begin{array}{l}\text { Highest \% of Expungements Relative to Misconduct } \\
\text { Infraction }\end{array}$ & $\mathrm{p}$ & $\begin{array}{c}\text { Highest \% of Expungements Relative to Total } \\
\text { Brokers }\end{array}$ & $\mathrm{p}$ & $\begin{array}{c}\text { Highest \% of Expungements Relative to Retail } \\
\text { Brokers }\end{array}$ & $\mathrm{p}$ \\
\hline Morgan Stanley & 512 & Sidoti \& Company, LLC & $400 \%$ & UBS Financial Services Incorporated Of Puerto Rico & $4 \%$ & Ace Diversified Capital, Inc & $100 \%$ \\
\hline Wells Fargo Clearing Services, LLC & 479 & Carolina Financial Securities, LLC & $300 \%$ & NSM Securities, Inc & $4 \%$ & RP Capital LLC & $33 \%$ \\
\hline Merrill Lynch, Pierce, Fenner \& Smith Incorporated & 391 & Samuel A Ramirez \& Co, Inc & $200 \%$ & Portfolio Advisors Alliance, LLC & $3 \%$ & Kensington Capital Corp & $27 \%$ \\
\hline UBS Financial Services Inc & 361 & Bristol Financial Services, Inc & $200 \%$ & Accelerated Capital Group & $3 \%$ & The Delta Company & $25 \%$ \\
\hline Ameriprise Financial Services, Inc & 165 & Cabin Securities, Inc & $150 \%$ & Network 1 Financial Securities Inc & $3 \%$ & Accelerated Capital Group & $23 \%$ \\
\hline LPL Financial LLC & 141 & Interactive Brokers Corp & $100 \%$ & First Standard Financial Company LLC & $3 \%$ & Lighthouse Capital Corporation & $18 \%$ \\
\hline Edward Jones & 115 & Fieldpoint Private Securities, LLC & $100 \%$ & RP Capital LLC & $2 \%$ & RW Towt \& Associates & $17 \%$ \\
\hline Charles Schwab \& Co, Inc & 98 & JMP Securities LLC & $100 \%$ & Kensington Capital Corp & $2 \%$ & ITRADEDIRECT.COM Corp & $17 \%$ \\
\hline Securities America, Inc & 74 & America Northcoast Securities, Inc & $100 \%$ & Allied Millennial Partners, LLC & $2 \%$ & Advantage Securities LLC & $14 \%$ \\
\hline Stifel, Nicolaus \& Company, Incorporated & 70 & Burch \& Company, Inc & $100 \%$ & Brookville Capital Partners & $2 \%$ & Navian Capital Securities LLC & $14 \%$ \\
\hline
\end{tabular}


Table 8. Panel B. This table examines employment outcomes for a random sample of 1,515 brokers who applied for expungement and experienced at least one separation. Column (1) records the most popular destinations for brokers who switched roles prior to the expungement award. Column (2) records the most popular destinations for brokers who switched roles after a successful expungement award. Column (3) records the most popular destinations for brokers who switched roles after an unsuccessful expungement award.

\begin{tabular}{|c|c|c|c|c|c|c|c|c|}
\hline Career Switches Before Expungement Award & $\mathrm{N}$ & $\mathrm{p}$ & $\begin{array}{c}\text { Career Switches After Successful } \\
\text { Expungement Award }\end{array}$ & $\mathrm{N}$ & $\mathrm{p}$ & $\begin{array}{c}\text { Career Switches After Unsuccessful } \\
\text { Expungement Award }\end{array}$ & $\mathrm{N}$ & $\mathrm{p}$ \\
\hline FINRA-Registered Firm in Registered Capacity & 1147 & $90 \%$ & FINRA-Registered Firm in Registered Capacity & 408 & $68 \%$ & FINRA-Registered Firm in Registered Capacity & 199 & $56 \%$ \\
\hline Unregistered Financial Firm & 23 & $2 \%$ & Unregistered Financial Firm & 28 & $5 \%$ & Unregistered Financial Firm & 35 & $10 \%$ \\
\hline FINRA-Registered Firm in Unregistered Capacity & 21 & $2 \%$ & FINRA-Registered Firm in Unregistered Capacity & 28 & $5 \%$ & FINRA-Registered Firm in Unregistered Capacity & 17 & $5 \%$ \\
\hline Non-Financial Company & 14 & $1 \%$ & Non-Financial Company & 33 & $6 \%$ & Non-Financial Company & 12 & $3 \%$ \\
\hline Unknown & 63 & $5 \%$ & Unknown & 86 & $14 \%$ & Unknown & 84 & $24 \%$ \\
\hline Non-Profit/Government & 2 & $0 \%$ & Non-Profit/Government & 4 & $1 \%$ & Non-Profit/Government & 2 & $1 \%$ \\
\hline Self-Employed & 1 & $0 \%$ & Self-Employed & 3 & $1 \%$ & Self-Employed & 0 & $0 \%$ \\
\hline Retired & 2 & $0 \%$ & Retired & 1 & $0 \%$ & Retired & 3 & $1 \%$ \\
\hline Prison & 0 & $0 \%$ & Prison & 0 & $0 \%$ & Prison & 2 & $1 \%$ \\
\hline University & 2 & $0 \%$ & University & 3 & $1 \%$ & University & 0 & $0 \%$ \\
\hline Unemployed & 0 & $0 \%$ & Unemployed & 3 & $1 \%$ & Unemployed & 1 & $0 \%$ \\
\hline Deceased & 0 & $0 \%$ & Deceased & 2 & $0 \%$ & Deceased & 1 & $0 \%$ \\
\hline Number of Unique Brokers & 799 & & & 396 & & & 240 & \\
\hline Total Switches & 1,275 & & & 599 & & & 355 & \\
\hline
\end{tabular}

